\title{
Yeni Halilcilik Kuramının Temel Kavramları Üzerine Bir İnceleme
}

\section{A Study on the Basic Concepts of Neo-Khalilian Theory}

\section{Bünyamin Aydın}

Dr. Öğretim Üyesi, Kastamonu Üniversitesi, İlahiyat Fakültesi, Arap Dili ve Belagatı Anabilim Dalı Assist. Prof., Kastamonu University, Faculty of Theology, Department of Arabic Language Kastamonu, Turkey

bunyaminayd@gmail.com | https://orcid.org/0000-0002-4495-6392

Article Type / Makale Tipi

Research Article / Araștırma Makalesi

DOI: $10.33420 /$ marife.977411
Article Information / Makale Bilgisi

Received / Geliș Tarihi: 01.08.2021

Accepted / Kabul Tarihi: 10.12.2021

Published / Yayın Tarihi: 30.12.2021

Cite as / Atıf: Aydın, Bünyamin. "Yeni Halilcilik Kuramının Temel Kavramları Üzerine Bir İnceleme". Marife 21/2 (2021): 1149-1174. https://doi.org/10.33420/marife.977411

Plagiarism / Intihal: This article has been reviewed by at least two referees and scanned via a plagiarism software. / Bu makale, en az iki hakem tarafından incelendi ve intihal içermediği teyit edildi.

\section{(c) $(1) \odot$}

Copyright / Telif Hakkl: "This article is an open access article distributed under the terms and conditions of the Creative Commons Attribution-NonCommercial-NoDerivatives 4.0 (CC BY-NC-ND 4.0) International License." / "Bu makale Creative Commons Alıntı-GayriTicari-Türetilemez 4.0 (CC BY-NCND 4.0) Uluslar arası Lisansı altında lisanslanmıștır."

e-ISSN : 2630-5550

www.marife.org 


\section{Yeni Halilcilik Kuramının Temel Kavramları Üzerine Bir İnceleme}

\section{Özet}

Nahiv ilmine dair çalışmaları öncekiler (evvelûn) ve sonrakiler (müteahhirûn) şeklinde ikiye ayırma düşüncesi, erken dönem nahiv bilginleri ile sonrakiler arasında çözümleme yöntemi bakımından önemli farklılıklar bulunduğu görüşünü içinde barındırır. Söz konusu farklılık, bilimsel araştırma yöntemine sahip olmak bakımından sonrakilerin aleyhine bir yargıyı da içerir. Bu görüşe göre Halîl b. Ahmed'in (ö. 175/791) bașta Sîbeveyhi (ö. 180/796) olmak üzere hicrî dördüncü yüzyıla kadar birçok nahiv bilgini tarafından takip edilen yaklaşımı sonrakiler tarafından terk edilmiş, nahive ait kavramlar bağlamlarından koparılmış ve nahivde öğreticilik ön plana çıkarılmıştır. Cezayirli dilbilimci Abdurrahmân el-Hâc Sâlih'in (ö. 2017) ortaya koyduğu Yeni Halilcilik Kuramı, sonraki nahiv bilginlerine getirilen eleștiriden hareketle Halîl b. Ahmed'in bașta el-Kitâb olmak üzere nahiv kitaplarında aktarılan görüșlerinin yeni bir okuması olarak nitelendirilebilir.

Abdurrahmân el-Hâc Sâlih, Arap grameri ifadesiyle Halîl b. Ahmed'in, Sîbeveyhi'nin ve ikisinin takipçilerinin çalışmalarına işaret etmektedir. Ona göre dördüncü yüzyıl sonrası nahiv kitapları, bazı münferit çalışmalar hariç tutulduğunda, Halîl b. Ahmed ve Sîbeveyhi'nin nahiv kuramını yansitmamaktadır. Özellikle istikâmet, lafza, misâl ve mevdı` gibi erken döneme ait temel kavramlar; sonraki nahiv bilginleri tarafından yeterince değerlendirilmemiștir. Yeni Halilcilik Kuramı'nın amacı, Halîl b. Ahmed ve Sîbeveyhi'nin geliştirdikleri nahiv kuramını bilimsel bir bakış açısıla ortaya koymaktır. Buna göre dilbilimci; erken dönem nahiv kavramlarını doğru bir biçimde anlayabilmek için kavramın geçtiği tüm bağlamları gözden geçirmelidir. Bunu yaparken bilimsel bir bakış açısına sahip olmalı ve modern dilbilime ait kavramları nahiv geleneğini açılamak için kullanmamalıdır. Bunların yanı sıra modern dilbilim kuramlarını herhangi bir ekole bağlı kalmaksızın incelemek, kurama getirilen eleștirileri dikkate almak ve modern epistemolojiye ait kavramları değerlendirmek de sağlıklı bir araștırmanın temel şartları arasındadır. Böyle bir araștırma sonucunda Arap gramerinin dayandığı temel yöntemsel ilkeler betimlenmiş olacak ve bunlar Yapısalcılık ve ÜreticiDönüşümsel Dilbilgisi gibi modern dilbilim ekollerinin dayandığı temel ilkelerle karşılaștırılabilecektir.

Abdurrahmân el-Hâc Sâlih, Yeni Halilcilik Kuramı adlandırmasının kendisine ait olmadığını belirtmektedir. O, konuyu ilk kez 1979'da doktora tezi çalışması kapsamında ele almış, Cezayir dışındaki bazı dilbilimciler bunu Yeni Halilcilik Kuramı olarak adlandırmış ve kendisi de bu adlandırmayı kabul etmiştir. Ona göre hedef, modern dilbilimde yapılanın tekrarını yapmak değil, özgün nahiv kuramına ait temel kavramları tanımlamak ve süreci kaldığı yerden devam ettirmektir. Abdurrahmân el-Hâc Sâlih'e göre erken dönem nahiv bilginlerinin çalışmalarında belirgin bir biçimde görülen ilk husus lafız-mana arasındaki ayrımdır. Bu ayrım Sîbeveyhi'nin ifadesiyle istikâmet kavramında kendini göstermektedir. Cümleye ilişkin müstakim-muhal ayrımı, nahiv bilginlerinin anlama ilişkin hususlarla lafza ilişkin hususları bir arada ele aldıklarını ve cümlenin anlamsal terkibi ile gramatik terkibi arasındaki ilișkiyi ortaya koymayı hedeflediklerini göstermektedir. Bu yaklașım biçimi isim ve fiil gibi kelime türlerinin tanımında da görülmektedir. Nitekim isim ve fiil, lafza ilişkin hususlar gözetilerek tanımlanabildiği gibi anlamsal hususlar dikkate alınarak da tanımlanabilmektedir. Abdurrahmân el-Hâc Sâlih'in üzerinde durduğu bir diğer kavram, lafza kavramıdır. Kelimeden büyük ve cümleden küçük yapılara işaret eden lafza, onun anlambirimler için yaptığı tasnifte üçüncü sırada yer almaktadır. Bu tasnifte kelimeden küçük anlambirim, kelime ve lafza olmak üzere Arap dilinde üç tür anlambirim sıralanmıştır. O, erken dönem nahiv bilginlerinin soyutlama becerisine dikkat çekmiş ve bu bağlamda mevdıc ve misâl kavramlarının önemini vurgulamıştır. Mevdı', dilsel birimlerin bütün içinde -kendine özgü vazî işlevini yerine getirdiği- özel konuma; misâl ise bu konumların toplamı mesabesindeki soyut kalıba işaret etmektedir. Dolayısıyla misâl, kelime, lafza ve cümle düzeylerinde ortaya çıkabilmektedir. Nahiv bilginleri her düzey için asıl mesabesinde bir misâl belirlemişler ve bu asıldan fer'ler türetmişlerdir. Abdurrahmân el-Hâc Sâlih'in Yeni Halilcilik Kuramı çerçevesinde ele aldığı bir diğer kavram, 'âmil kavramıdır. 'Âmil özellikle cümle düzeyindeki misâl ile ilgilidir. Nitekim isim cümlesinde ibtidâ, mübtedâ ve haber mevdı ları, fiil cümlesinde de fiil, fâil ve mef ûl mevdı ları Arap dilinde cümle düzeyindeki misâli oluşturmaktadır. Bu da ona göre, cümlenin sözü edilen soyut unsurlardan oluştuğunu göstermektedir. Bu çalışmada Yeni Halilcilik Kuramı'nın temel kavramları, Abdurrahmân el-Hâc Sâlih'in erken dönem nahiv bilginlerine dair değerlendirmelerini içeren farklı yazıları üzerinden ve temel nahiv eserlerine müracaat edilmek 
suretiyle ele alınacaktır.

Anahtar Kelimeler: Arap Dili, Abdurrahmân el-Hâc Sâlih, Yeni Halilcilik Kuramı, Arap Grameri, Dilbilim

\section{A Study on the Basic Concepts of Neo-Khalilian Theory}

\section{Summary}

The idea of dividing the nahw studies into two as the previous scholars and the late period scholars includes the view that there are important differences between the early period nahw scholars and the later ones in terms of analysis method. The mentioned difference also includes a judgment against the late period scholars in terms of having a scientific research method. According to that the approach of Khalil b. Ahmad (d. 175/791), which was followed by many nahw scholars, especially Sïbawayh (d. 180/796), until the fourth century was abandoned by the later ones and the nahw concepts have been decontextualized and the didactic quality has become important in nahw. Neo-Khalilian Theory set forth by the Algerian linguist 'Abd Al-Rahmān Al-Hāj Sāleh (d. 2017) and based on the criticism directed to the late period nahw scholars can be considered as a new reading of Khalil's views conveyed in nahw books, especially in al-Kitâb.

'Abd Al-Rahmān Al-Hāj Sāleh refers to the work of Khalīl b. Ahmad, Sībawayh and their followers by the concept of Arabic grammar. According to him, nahw books after the fourth century AH don't reflect the grammatical theory put forward by Khalil and Sibawayh, with the exception of some individual studies. In particular, the basic concepts of the early period such as istiqaimah, lafzah, misāl and mawdic were not adequately evaluated by later nahw scholars. The aim of the Neo-Khalilian Theory is to reveal the theory of nahw developed by Khalil and Sïbawayh from a scientific point of view. Accordingly, the linguist, in order to properly understand early nahw concepts, he should review all the contexts in which the concept was used. The linguist must have a scientific viewpoint that is free of biases and must not use the concepts of modern linguistics to explain the concepts of nahw. In addition, studying on the theories of modern linguistics without being bound by any school, taking into account the criticisms made of the theory and evaluating the concepts of modern epistemology are among the essential conditions for correct research. As a result of such a research, the basic methodological principles on which Arabic grammar is based will be described and these will be compared with the basic principles on which modern linguistic schools such as Structuralism and Generative-Transformational Linguistics are based.

'Abd Al-Rahmān Al-Hāj Sāleh remarks that he didn't name the Neo-Khalīlian Theory himself. He dealt with the subject for the first time within the scope of his doctoral thesis in 1979 and some linguists from outside Algeria called it "Neo-Khalilian Theory" and he himself accepted this name. According to him, the goal is not to repeat what has been accomplished in modern linguistics, but to define the basic concepts of the original theory of nahw and to continue the process where it left off.

According to 'Abd Al-Rahmān Al-Hāj Sāleh, the first point that seen clearly in the work of early nahw scholars is the distinction between form and meaning. This distinction appears in the concept of istiqāmah, in the words of Sïbawayh. The distinction between mustaqīm and muhāl in the sentence shows that nahw scholars deal with both semantic and grammatical issues and aim to reveal the relationship between the semantic structure of a sentence and its grammatical structure. This approach also appears in the definition of noun and verb. For, they can be defined by considering the grammatical aspects as well as by considering the semantic aspects. Another concept that 'Abd AlRahmān Al-Hāj Sāleh emphasizes is the concept of lafzah. Lafzah which refers to structures larger than words and smaller than sentences takes the third place in his classification for morphemes. In this classification, three types of morphemes have been listed in the Arabic language. The first one is morpheme which is smaller than word and the second one is the word and the third one is lafzah. 'Abd Al-Rahmān Al-Hāj Sāleh drew attention to the abstraction skills of early nahw scholars and emphasized the importance of the concepts of mawdi ‘ and misāl in this context. Mawdic refers to the special positions of the units in the structure, where they perform their certain function and misāl refers to the abstract pattern as the sum of these positions. Therefore, misāl can occur at the level of word, lafzah and sentence. Nahw scholars have defined a misāl for each level and generated many units from this origin. Another concept that 'Abd Al-Rahmān Al-Hāj Sāleh dealt with within the scope of the Neo-Khalīlian Theory is the concept of 'ämil. 'Āmil is specifically related to the misāl at the sentence level. For, in the noun clause, ibtidā, mubtedā and khabar positions, and in the verbal sentence, verb, subject and object positions constitute misāl at the sentence level. This reveals that the 
sentence, according to 'Abd Al-Rahmān Al-Hāj Sāleh, consists of the above-mentioned abstract elements. In this study, the basic concepts of the Neo-Khalilian Theory will be discussed through the different writings of 'Abd Al-Rahmān Al-Hāj Sāleh, which include his evaluations about early nahw scholars, and by referring to the basic nahw books.

Keywords: Arabic Language, 'Abd Al-Rahmān Al-Hāj Sāleh, Neo-Khalīlian Theory, Arabic Grammar, Linguistics

\section{Giriş}

Abdurrahmân el-Hâc Sâlih (1927-2017), Yeni Halilcilik Kuramı ( النظرية الخليلية (الحديثة) ve Arap Dilinin Söz Varlığı Projesi (مشروع الذخيرة اللغوية العربية) gibi bilimsel çalışmalarıyla öne çıkan Cezayirli bir dilbilimcidir. Kahire, Bordeaux ve Paris'te Arap dili ve edebiyatı, tıp, hukuk ve dilbilim eğitimi almıştır. Cezayir Üniversitesi'nde Arap Dili hocalığı (1962), Arap Dili ve Dilbilim bölüm başkanlıkları (1963), Edebiyat Fakültesi dekanlığı (1965), Dilbilim Enstitüsü müdürlüğü (1966) görevlerinde bulunmuş; Sorbonne Üniversitesi'nde dilbilim doktorası yapmıştır (1979). Şam, Bağdat, Amman ve Kahire Arap Dili Akademilerinde üye olarak yer alan Abdurrahmân el-Hâc Sâlih, 2000 yılında Cezayir Arap Dili Akademisi Başkanlığı'na seçilmiştir. Arapça, İngilizce ve Fransızca bilimsel makaleler yayınlayan Abdurrahmân el-Hâc Sâlih 2017 yılında Cezayir'de vefat etmiştir. ${ }^{1}$

Abdurrahmân el-Hâc Sâlih, Arap grameri ifadesiyle, Halîl b. Ahmed'in (ö. 175/791), Sîbeveyhi'nin (ö. 180/796) ve bu ikisinin takipçilerinin çalışmalarına işaret ettiğini belirtmektedir. ${ }^{2}$ Geliştirdiği Yeni Halilcilik Kuramı, Halîl b. Ahmed'in başta el-Kitâb olmak üzere nahiv kitaplarında aktarılan görüşlerinin yeni bir okuması olarak nitelendirilebilir. Buna göre hicrî dördüncü yüzyıl sonrası nahiv kitapları, bazı münferit çalışmalar hariç tutulduğunda, Halîl b. Ahmed ve Sîbeveyhi'nin ortaya koydukları nahiv kuramını yansıtmamaktadır. Özellikle mevdı (المَوْضِع), lafza (اللَََّْْة) ve misâl (المِثَّال) gibi erken döneme ait temel kavramlar; sonraki nahiv bilginleri tarafından yeterince değerlendirilmemiştir. Yeni Halilcilik Kuramı'nın amacı, Halîl b. Ahmed ve Sîbeveyhi'nin ortaya koydukları nahiv kuramını bilimsel bir bakış açısıyla değerlendirmektir. Abdurrahmân el-Hâc Sâlih'e göre dilbilimci; erken dönem nahiv bilginlerinin ortaya koydukları kavramları anlayabilmek için kavramın geçtiği tüm bağlamlara bakmalı ve şârihlerin yorumlarıyla yetinmemelidir. Bunu yaparken ön yargılardan uzak bilimsel bir bakış açısına sahip olmalı ve modern dilbilime ait kavramları nahiv geleneğini açıklamak için kullanmamalıdır. Bunların yanı sıra modern dilbilim kuramlarını herhangi bir ekole bağlı kalmaksızın incelemek, kurama getirilen eleştirileri dikkate almak ve modern epistemolojiye ait kavramları değerlendirmek de sağlıklı bir araştırmanın temel şartları arasındadır. Böyle bir araştırma sonucunda Arap gramerinin dayandığı temel yöntem-

\footnotetext{
${ }^{1}$ Verde Suhrî, el-Cuhûdu'l-Lisâniyye 'inde'd-Duktûr Abdurrahmân el-Hâc Sâlih min hilâli Buhûs ve Dirâsât fí 'Ulûmi'l-Lisân (Batna: Câmiatu Batna, Kulliyyetu'l-Luga ve'l-Edebi'l-'Arabî ve'l-Funûn, Yüksek Lisans Tezi, 2016), Ek, 1-9; el-Lecnetu'l-Vataniyye li’z-Zehîrati'l-Lugaviyye (ez-Zehîratu'l-Lugaviyye), “es-Sîratü'z-Zâtiyye li'l-Ustâz ed-Duktûr Abdurrahmân el-Hâc Sâlih" (Erişim 22 Temmuz 2021).

2 Abdurrahmân el-Hâc Sâlih, "en-Nahvu'l-‘Arabî ve'l-Bineviyye”, Mecelletu Mecme'i'l-Lugati'l'Arabiyye 85 (Mayıs 1999), 197-198.
} 
sel ilkeler betimlenmiş olacak ve bunları Yapısalcılık ve Üretici-Dönüşümsel Dilbilgisi gibi modern dilbilim ekollerinin dayandığı temel ilkelerle karşılaştırma imkânı doğacaktır. ${ }^{3}$

Abdurrahmân el-Hâc Sâlih'e göre araştırmacı, doğuya ve batıya ait tüm nazariyeleri eleştiri süzgecinden geçirmeli, bunlardan herhangi birine bağlı kalmamalıdır. Dolayısıyla ne İbn Mâlik (ö. 672/1274) ve İbn Hişâm’ın (ö. 761/1360) taklidiyle yetinilmeli ne de modern dilbilim kuramlarından birine bağlanılmalıdır. Yapılacak olan bilimsel ve nesnel bir bakış açısıyla erken dönem nahiv kuramının ortaya konulması ve modern dilbilim kuramlarıyla bir arada değerlendirilmesidir. Bunun için araştırmacı özgün nahiv kuramıyla arasındaki engeli (diğer nahiv kitapları) aşmalı ve doğrudan temel eserlere ulașmalıdır. ${ }^{4}$ Abdurrahmân el-Hâc Sâlih elKitâb hakkında şöyle demektedir:

“Sîbeveyhi'nin $e l-K i t a ̂ b$ 'ı üzerinde uzun süren araştırmalar yaptık ve anladık ki bu kitapta yer alan kavramlar, eski veya yeni herhangi bir kuramda görmediğimiz bir biçimde, özgün bir dil kuramı ortaya koyuyor. Bu kavramlar ortaya çıkarılarak Sîbeveyhi'nin ve özellikle de hocası Halîl b. Ahmed'in bunlarla neyi kastettikleri tespit edilmelidir."5

Abdurrahmân el-Hâc Sâlih'in -yukarıdaki ifadelerinde görüldüğü üzere- bilimsel çalışmalarında üzerinde özellikle durduğu hususlardan biri nahiv ilminin özgünlüğü tartışmasıdır. 0, daha önce İbrahim Medkûr (ö. 1996) gibi isimlerin değindiği ${ }^{6}$ Aristo mantığının Arap gramerini konu ve yöntem bakımlarından etkilediği yönündeki görüşü benimsememektedir. Şevkî Dayf'ın (ö. 2005) ifadesiyle,

“0, Arap gramerinin mantık ilminden etkilenmiş olduğu fikrini kabul etmez. Ona göre nahiv ilmi, özgün ve dilbilimsel bir karaktere sahiptir."7

Abdurrahmân el-Hâc Sâlih'e göre Arap gramerinin kurucuları ve teorisyenleri olan Halîl b. Ahmed ve Sîbeveyhi gibi isimler, bu çalışmaların özgünlük ve yetkinliğini temsil etmektedirler. Dördüncü yüzylddan sonra dilciler, Abdülkâhir elCürcânî (ö. 471/1078), Süheylî (ö. 581/1185) ve Radî el-Esterâbâdî (ö. 688/1289) gibi münferit isimler istisna edildiğinde, bu isimlerin ulaştıkları yaratıcılık ve derinlik düzeyine ulaşamamışlardır. ${ }^{8}$ Dolayısıyla Halîl b. Ahmed'in ortaya koyduğu ve

3 Abdurrahmân el-Hâc Sâlih, "Mukaddime”, Kurrâsetu Merkezi'l-Bahsi'l-'ilmî ve't-Tekanî li Tatvîri'lLugati'l-'Arabiyye 4 (2007), 7; Abdurrahmân el-Hâc Sâlih, "el-Medrasetu'l-Halîliyyetu'l-Hadîse ve'dDirâsâtu'l-Lisâniyyetu'l-Hâliyye fi'l-‘Âlemi'l- 'Ârabî”, Kurrâsetu Merkezi'l-Bahsi'l-'ílmî ve't-Tekanî li Tatvîri'l-Lugati'l-'Arabiyye 4 (2007), 16.

4 Abdurrahmân el-Hâc Sâlih, “el-Medrasetu'l-Halîliyyetu'l-Hadîse ve'd-Dirâsâtu'l-Lisâniyyetu'l-Hâliyye fi'l-'Âlemi'l-'Ârabî”, 93-94.

5 Abdurrahmân el-Hâc Sâlih, Buhûs ve Dirâsât fi'l-Lisâniyyâti'l-'Arabiyye (Cezayir: el-Muessesetu'lVataniyye li'l-Funûni'l-Matbaciyye, 2012), 2/81.

6 İbrahim Medkûr, “Mantıku Aristo ve'n-Nahvu'l-‘Arabî”, Mecelletu Mecme'i'l-Lugati'l-'Arabiyye 7 (1953), 338-346.

7 Şevkî Dayf, "Takdim”, Buhûs ve Dirâsât fi'l-Lisâniyyâti'l-'Arabiyye, mlf. Abdurrahmân el-Hâc Sâlih (Cezayir: el-Muessesetu'l-Vataniyye li'l-Funûni'l-Matbaciyye, 2012), 1/7.

8 Abdurrahmân el-Hâc Sâlih, "en-Nahvu'l-'Arabî ve'l-Bineviyye”, 198; Abdurrahmân el-Hâc Sâlih, "Mukaddime", 5; Abdurrahmân el-Hâc Sâlih, "el-Cumle fî Kitâbi Sîbeveyhi", Mecelletu Mecme'i’lLugati'l-'Arabiyye 78 (Mayıs 1996), 100. 
Sîbeveyhi'nin geliștirdiği nahiv kuramının temel kavramları ve metodolojisi ortaya konulmalıdır. Abdurrahmân el-Hâc Sâlih, ilk kez 1979'da doktora tezi olarak ele aldığı bu konu üzerinde yaptığı çalıșmaların Cezayir dışındaki bazı dilbilimciler tarafından "Yeni Halilcilik Kuramı" olarak adlandırıldığını ve kendisinin de bu adlandırmayı kabul ettiğini belirtir. ${ }^{9}$ Yeni Halilcilik Kuramına ait çalışmalar, Sîbeveyhi'nin ve hocalarının, özellikle Halîl b. Ahmed'in, ürettikleri fikirlerin temelini oluşturan dil kuramını açık bir biçimde ortaya koymayı hedeflemektedir. ${ }^{10} \mathrm{Bu}$ hedef, özellikle dördüncü yüzyıl sonrası nahiv bilginlerinin söz konusu dil teorisinden farklı bir yerde konumlandıkları iddiasını içinde barındırmaktadır. Nitekim kullanılan terimler aynı olsa da çıkış noktası, bakış açısı ve çözümleme yöntemi bakımından önemli farklılıklar bulunmaktadır. ${ }^{11}$ Yeni Halilcilik Kuramı adı altındaki çalışmalarda yöntemsel açıdan önce nahiv ilminin dayandığı temel kavramlar ve yöntemsel ilkeler betimlenmekte, sonra bunlar modern dilbilim ekollerine (özellikle yapısalcılık ve üretici-dönüşümsel dilbilgisi) ait temel ilkelerle karşılaştırılmaktadır. ${ }^{12}$ Yeni Halilcilik Kuramı açısından, sonraki nahiv bilginlerinin değerlendirme ve şerhleri öncekilerin çoğunlukla yanlış anlașılmış tekrarları olarak ortaya çıkmaktadır. Abdurrahmân el-Hâc Sâlih'e göre İbnü'l-Haşşâb (ö. 567/1172), İbn Mâlik gibi nahiv bilginlerinin kelime kavramına getirdikleri tanımlar, ${ }^{13}$ Sîbeveyhi'nin tasavvurundan çok uzaktır. ${ }^{14}$ Dolayısıyla burada karşılaşılabilecek problemlerden ilki, eskilerin kullandıkları kavramlarla yenilerin onları kullanış biçimlerini ayırt etme problemidir. ${ }^{15}$

Abdurrahmân el-Hâc Sâlih'e göre Yeni Halilcilik Kuramı Arap dünyasında iki farklı dilbilimsel eğilim arasında yer almaktadır. Bunlardan ilki modern dilbilim okullarından büyük ölçüde habersizdir. Bu eğilim nahiv ilminin belli bir dönemden sonra kanun haline gelen ve kurucu isimlerin tasavvurlarından uzaklaşan kavramlarını esas alır. İkincisi ise modern dilbilim teorilerine dayanan eğilimdir. Bu eğilime sahip araştırmacıların bir kısmı nahiv geleneğinden büyük ölçüde habersizdirler ve geleneği tıpkı birinciler gibi tek tip zannetmektedirler. Diğer bir kısım ise geleneği bir ölçüde bilmekle beraber onun artık yetersiz kaldığını düşünmektedir. Her iki eğilime sahip dilbilimciler de önemli çalışmalar yapmışlardır. Birinci eğilimde Sîbeveyhi'in el-Kitâb'ı gibi klasikler tahkik edilmiş, ihyâu't-turâs (geleneği

${ }^{9}$ Abdurrahmân el-Hâc Sâlih, "Mukaddime", 5, 11.

10 Abdurrahmân el-Hâc Sâlih, “el-Medrasetu'l-Halîliyyetu'l-Hadîse ve'd-Dirâsâtu'l-Lisâniyyetu'l-Hâliyye fi'l- ‘̂̂lemi'l-‘Ârabî”, 15.

11 Abdurrahmân el-Hâc Sâlih, "Mukaddime", 7; Abdurrahmân el-Hâc Sâlih, "el-Cumle fî Kitâbi Sîbeveyhi", 98.

12 Abdurrahmân el-Hâc Sâlih, “el-Medrasetu'l-Halîliyyetu'l-Hadîse ve'd-Dirâsâtu'l-Lisâniyyetu'l-Hâliyye fi'l- 'Âlemi'l-`Ârabî”, 15.

13 İlgili tanımlar için bk. Cemâlüddîn Muhammed b. Abdillah İbn Mâlik, Şerhu Teshîli'l-Fevâid ve Tekmîli'l-Makâsıd, thk. Abdülkâdir 'Atâ - Târık Fethî es-Seyyid (Beyrut: Dâru'l-Kutubi'l-'Illmiyye, 2001), 1/12; Ebû Muhammed Abdullah b. Ahmed İbnü'l-Haşşâb, el-Mürtecel, thk. Ali Haydar (Dımaşk: 1972), 4-5.

14 Abdurrahmân el-Hâc Sâlih, "Mukaddime", 7-9.

15 Abdurrahmân el-Hâc Sâlih, “el-Medrasetu'l-Halîliyyetu'l-Hadîse ve'd-Dirâsâtu'l-Lisâniyyetu'l-Hâliyye fi'l-'Âlemi'l-'Ârabî”, 43. 
canlandırma) çalışmaları kapsamında yazma eserler ortaya çıkarılmıştır. İkinci eğilimde de Ferdinand de Saussure (ö. 1913), Nikolay Trubetskoy (ö. 1938), John Rupert Firth (ö. 1960), André Martinet (ö. 1999), Noam Chomsky (1928-...) gibi dilbilimcilerin görüşleri etrafında yeni ve önemli çalışmalar ortaya konulmuştur. Yeni Halilcilik Kuramı açısından önemli olan husus, nahiv ilmine ait kavramların modern dilbilim ekollerine ait kavramlar üzerinden yorumlanmamasıdır. ${ }^{16}$ Yapılmak istenen Avrupa'da yapılanı tekrarlamak değil, nahiv ilmine ait temel kuram ve kavramları ortaya çıkarıp süreci kaldığı yerden devam ettirmektir. ${ }^{17}$

Özetle Yeni Halilcilik Kuramı sonraki nahivcilerin, erken dönem nahiv bilginlerinin dilin betimlenmesi yoluyla ürettikleri temel kavramları doğru değerlendirmedikleri düșüncesi üzerine kuruludur. Söz konusu kavramlar, Abdurrahmân el-Hâc Sâlih'in konuya ilişkin farklı yazıları üzerinden ve Sîbeveyhi'nin el-Kitâb'ı başta olmak üzere temel nahiv eserlerine müracaat edilmek suretiyle burada ele alınacaktır.

\section{Yeni Halilcilik Kuramının Temel Kavramları}

Abdurrahmân el-Hâc Sâlih'in Yeni Halilcilik Kuramı'na dair farklı yazılarında lafız-mana ayrımı, istikâmet (الاستقامة), infirad (الانفراد), lafza (اللفظة), mevdı (الموضع), misâl (العامل) ve 'alâme 'ademiyye (المثال), âmil (العلامة العدمية) gibi temel kavramlar ön plana çıkmaktadır.

\section{1. İstikâmet ve Lafız-Mana Ayrımı}

İstikâmet terimi her şeyden önce lafza ilişkin hususlarla anlama ilişkin hususlar arasındaki kesin bir ayrıma işaret etmektedir. ${ }^{18}$ Sîbeveyhi'ye göre;

"Kelam; müstakim-hasen, muhal, müstakim-kezib, müstakim-kabih ve muhalسَآتِيكَ غَدًا (Yarın sana geleceğim.) gibi cümlelerdir. Muhal ise sözün başının, sonunu nakzet-

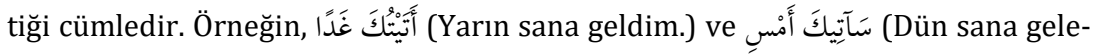
ceğim.) cümleleri böyledir. Müstakim-kezib, حملتُ الجبلَ (Dağı yüklendim.) ve شرِبْتُ مَاءَ البَحْر (Denizin suyunu içtim.) türünden cümlelerdir. Müstakim-kabih, lafzın, olmaması gereken bir konumda bulunduğu cümledir. Örneğin, قَدْ زَيْدًا رَأََْتُ (Gördüm Zeyd'i.) ve كَيْ زَيْدُ يَأِِْيكَ (Gelsin diye Zeyd sana.) cümleleri böyledir. Muhal-

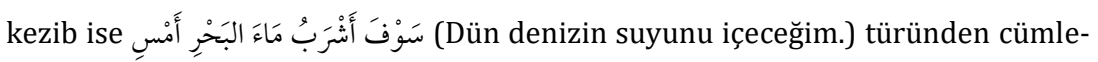

${ }^{16}$ Abdurrahmân el-Hâc Sâlih, “el-Medrasetu'l-Halîliyyetu'l-Hadîse ve'd-Dirâsâtu'l-Lisâniyyetu'l-Hâliyye fi'l-'Âlemi'l-'Ârabî", 44-46.

17 Abdurrahmân el-Hâc Sâlih, "el-Medrasetu'l-Halîliyyetu'l-Hadîse ve Meşâkilu 'illâci'l-'Arabiyye bi'lHâsûb”, Kurrâsetu Merkezi'l-Bahsi'l-'Ilmî ve't-Tekanî li Tatvîri'l-Lugati'l-'Arabiyye 4 (2007), 93.

18 Abdurrahmân el-Hâc Sâlih, "el-Medrasetu'l-Halîliyyetu'l-Hadîse ve'd-Dirâsâtu'l-Lisâniyyetu'l-Hâliyye fi'l-'Âlemi'l-'Ârabî”, 30. 
lerdir."19

Abdurrahmân el-Hâc Sâlih'e göre Sîbeveyhi bu tasnifiyle lafza ilișkin hususlarla anlama ilişkin hususları ayıran ilk dilci olarak cümlenin düzgünlüğü kavramını, gramatik doğruluk ve semantik geçerlilik açılarından ayrı ayrı değerlendirmiştir. ${ }^{20}$ Dolayısıyla Sîbeveyhi cümleyi gramatik terkip ve anlamsal terkip olmak üzere iki düzeyde ele almıştır. Abdurrahmân el-Hâc Sâlih'e göre Sîbeveyhi'nin tasnifinde müstakim-hasen ve müstakim-kabih terimleri lafza, müstakim ile muhal arasındaki karşıtlık ise anlama gönderimde bulunmaktadır. Tasnifteki bir diğer ayrım ise kıyasa (dilin cümle yapısına hâkim olan genel kurallar) ilişkin hususlar ile kullanıma (isti`mâl) ilişkin hususlar arasındaki ayrımdır. Buna göre; müstakim-hasen ( أَتَيُْكَ (أَمْسِ dilin cümle yapısına hâkim olan kurallar bakımından geçerli ve kullanıma uygun sözleri; müstakim-kabih (قَََْْيدًا رَأَيْتُ lahn düzeyinde bir aykırıllk ${ }^{21}$ olmamakla birlikte dilin cümle yapısına hâkim olan kurallar bakımından sorunlu ve kulla-

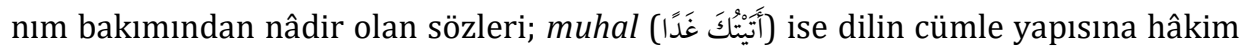
olan kurallara uygun olsa da aklen mümkün olmayan anlamsız sözleri ifade etmektedir. ${ }^{22}$

Sîbeveyhi'nin önce müstakim-hasen ile müstakim-kabih kavramları arasında daha sonra da bu ikisiyle muhal kavramı arasında bir ayrım yapması, öncelikle kıyasa uygun olan ve olmayan lafızlar arasında, sonra ise anlamlılık ile anlamsızlık arasında yapılmış bir ayrım olarak ortaya çıkmaktadır. Abdurrahmân el-Hâc Sâlih'e göre Abdülkâhir el-Cürcânî (ö. 471/1078) Delâilu'l-İcâz adlı eserini Sîbeveyhi'nin bu tasnifi üzerine kurgulamıştır. ${ }^{23}$

Sîbeveyhi'nin tasnifi, Abdurrahmân el-Hâc Sâlih dışında başka dilbilimciler tarafından da benzer bir bakış açısıyla yorumlanmıștır. Buna göre söz konusu tasnifte salt dilbilgisel sınırlar içinde kalınmamış, cümlenin anlamsal terkibi gramatik terkibi ile bir arada ele alınmış ve hem gramatik hem de semantik açıdan kabul

${ }^{19}$ Ebû Bişr Amr b. Osmân Sîbeveyhi, el-Kitâb, thk. Abdusselâm Muhammed Harun (Kahire: Mektebetu'lHancî, 1988), 1/25.

20 Abdurrahmân el-Hâc Sâlih, el-Hitâb ve't-Tehâtub (Cezayir: el-Muessesetu'l-Vataniyye li'l-Funûni'lMatba'iyye, 2012), 113.

21 Sîrâfî de (قََْ زَيْدًا رَأَيْتُ cümlesinde lahn düzeyinde bir hata bulunmadığını ve bu açıdan cümlenin müstakim olduğunu; ancak kelimelerin dizilişte olmaları gereken yerde bulunmamalarından dolayı Sîbeveyhi tarafından kabih olarak nitelendirildiğini belirtmektedir. Sîbeveyhi'nin bir diğer şârihi Rummâni ise müstakim-kabih yerine müstakim-zayıf terimini kullanmaktadır. Ona göre de cümlede anlam açısından bir çirkinlik bulunmamakta, kelimelerin doğru yere konulmamasından kaynaklanan bir çirkinlik bulunmaktadır. Bk. Ebû Saîd es-Sîrâfî, Şerhu Kitâbi Sîbeveyhi, thk. Ramazan Abduttevvâb vd. (Kahire: Dâru'l-Kutub ve'l-Vesâiku'l-Kavmiyye, 2008), 2/92; Ebu'l-Hasen Ali b. İsa er-Rummânî, Şerhu Kitâbi Sîbeveyhi, thk. Muhammed İbrahim Yûsuf Şeybe (Mekke: Ümmü'l-Kurâ Üniversitesi, 1415), 1/151.

22 Abdurrahmân el-Hâc Sâlih, “el-Medrasetu'l-Halîliyyetu'l-Hadîse ve'd-Dirâsâtu'l-Lisâniyyetu'l-Hâliyye fi'l-'Âlemi'l-'Ârabî”, 30-31; Abdurrahmân el-Hâc Sâlih, Buhûs ve Dirâsât fi'l-Lisâniyyâti'l-'Arabiyye, $2 / 52$.

${ }^{23}$ Abdurrahmân el-Hâc Sâlih, Buhûs ve Dirâsât fi'l-Lisâniyyâti'l-'Arabiyye, 2/52. 
edilebilir nitelikte cümleler üretmenin yolları araştırılmıştır. ${ }^{24}$ el-Kitâb'ın ortaya koyduğu nahiv, Arapçanın doğru bir şekilde kullanılmasını sağlayan kurallarla sınırlı kalmamış, Arap dili içerisinde düşünme ilkelerini tanımlamıștır. ${ }^{25}$ Dolayısıyla “Sîbeveyhi'nin yapmaya çalıştığı, dar anlamda bir dilbilgisi inşa etmek değil, Arapların düşünüş ilkelerini ve mantık ihlallerini ortaya koymaktır. Ortaya konulmak istenen mantık, Arap aklına özgü bir düşünüşün izlerini taşımaktadır."26 Bu durum, Sîbeveyhi'nin kullanımda olan (müsta'mel) cümlelerden getirdiği örnekler için geçerli olduğu gibi sadece örnek (temsil) olmak üzere ortaya koyduğu dilde kullanılmayan (mühmel) yapılar için de geçerlidir. ${ }^{27}$

Lafız ile mana arasındaki kesin ayrım, Abdurrahmân el-Hâc Sâlih'e göre, kelimenin tanımında da kendini gösterir. Buna göre, tanım anlamsal unsurlar gözetilerek yapıldığında çözümleme de anlamsal (sémantique) bir çözümleme olacaktır. Eğer tanım lafzî unsurlar dikkate alınarak yapılmışsa bu durumda çözümleme lafzî-gramatik (sémiologico-grammatical) bir çözümleme olacaktır. Örneğin fiilin anlam dikkate alınarak yapılan tanımı "iş ve zamana delalet eden lafı" ( مَا دّّلَّ عَلى حَدَثٍ

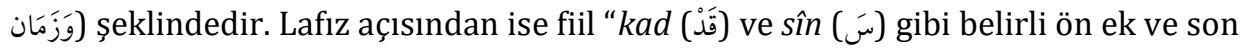
eklerin dâhil olduğu, bazı sıygalarında muttasıl zamir kabul eden lafız" şeklinde tanımlanır. Dolayısıyla tanımı bunlardan biriyle sınırlamak ve tanımda gözetilen yaklaşım biçimini görmezden gelmek hata olacaktır. Nahiv bilginleri burada her iki yaklaşımı da benimsemişlerdir. ${ }^{28}$

Biçimsel ve anlamsal unsurlar arasındaki bu ayrım, Halîl b. Ahmed ve onun görüşlerini takip eden nahiv bilginleri için son derece önemlidir ve nahiv ilminin temel yöntemsel ilkelerinden biridir. Buna göre herhangi bir dilsel unsur, bir lafız olarak, yalnızca anlamsal hususlar dikkate alınarak tanımlanmadığı gibi anlam da lafzın gönderileni olarak yalnızca lafza ilişkin hususlar gözetilerek tanımlanmaz. $\mathrm{Bu}$ ilke Yeni Halilcilik Kuramı'nın temel ayırıcı özelliklerindendir. ${ }^{29}$ Bununla birlikte zihne önce lafız sonra lafzın anlamı geldiğinden nahiv bilginleri çözümlemelerinde lafzı başlangıç noktası olarak kabul etmişlerdir. ${ }^{30}$ Nitekim Abdurrahmân elHâc Sâlih, Yeni Halilcilik Kuramı'nın temel kavramlarını açıkladığı bölümün sonunda şöyle bir değerlendirme yapmaktadır:

“Burada gördüğümüz tüm çözümlemeler lafız açısından yapılmış çözümlemeler-

${ }^{24}$ Hâdî Nehr, 'İlmu'd-Delâle et-Tatbîkî fi't-Turâsi'l-'Arabî (İrbid: Dâru'l-Emel, 2007), 113.

${ }^{25}$ Muhammed Hamâse Abdüllatîf, en-Nahv ve'd-Delâle (Kahire: Dâru'ş-Șurûk, 2000), 70-73; Muhammed Âbid el-Câbirî,, Binyetül'-'Akli'l-'Arabî (Beyrut: Merkezu Dirâsâti'l-Vahdeti'l-'Arabiyye, 2009), 44.

${ }^{26}$ Soner Gündüzöz, Arap Düşüncesinin Büyübozumu (Samsun: Etüt Yayınları, 2011), 84.

${ }^{27}$ Saîd Hasen Buhayrî, 'Anâsıru'n-Nazariyyeti'n-Nahviyye fî Kitâbi Sîbeveyhi (Kahire: Mektebetu'l-Anglo el-Mısriyye, 1989), 158, 161. Müstakim-muhal ayrımının üretici-dönüşümsel dilbilgisinde ele alınış biçimine dair bir değerlendirme için bk. Halîl Ahmed 'Amâyira, Fî Nahvi'l-Luga ve Terâkîbihâ Menhec ve Tatbîk (Cidde: 'Alemu'l-Ma'rife, 1984), 55-58.

${ }^{28}$ Abdurrahmân el-Hâc Sâlih, "el-Medrasetu'l-Halîliyyetu'l-Hadîse ve'd-Dirâsâtu'l-Lisâniyyetu'l-Hâliyye fi'l-'Âlemi'l-'Ârabî", 31.

${ }^{29}$ Abdurrahmân el-Hâc Sâlih, Buhûs ve Dirâsât fi'l-Lisâniyyâti'l'- 'Arabiyye, 2/84.

${ }^{30}$ Abdurrahmân el-Hâc Sâlih, "el-Medrasetu'l-Halîliyyetu'l-Hadîse ve'd-Dirâsâtu'l-Lisâniyyetu'l-Hâliyye fi'l-'Âlemi'l-'Ârabî”, 31. 
dir. Halîl'i takip eden nahivciler, (lafzı olduğu gibi) manayı da asıl ve fer ${ }^{`}$ olmak üzere ikiye ayırmışlardır. Asıl, lafzın delaletidir ve uzlașım ürünüdür. Fer ${ }^{c}$ ise hâlin delaleti, mananın delaleti gibi lafzî delalet dışında ortaya çıkan anlamlardır. Bu ferîi anlamlar asıl anlamdan aklî dönüştürüm işlemleri yoluyla çıkarılmaktadır. Bu anlamlara ait çalışma alanı meânî ve beyan ilimleridir."31

Abdurrahmân el-Hâc Sâlih buradan hareketle anlambirimlere ilişkin üçlü bir tasnif yapmıştır: Birinci grupta yer alan anlambirimler; dârib (خَارِب) kelimesindeki elif (1), mekteb (مَكْتَبَ) kelimesindeki mîm (م), ifti âl sıygasındaki tâ (ت) ve muzâraat harfleri gibi herhangi bir kelimenin yapısı içinde yer alan anlambirimlerdir. Bunlar nahiv bilginlerine göre kelime değildir. İkinci grupta yer alan anlambirimler; kitâb ve menzil gibi hem ayrı olarak bulunabilen (الإنْفِصَال التَّمّ) hem de tek başlarına kullanılabilen (قَابَلَ لِنِِنِْفرَاد) kelimelerdir. Üçüncü grupta yer alan anlambirimler; harf-i ta'rîf (ال), harf-i cerler, muttasıl zamirler, sîn (سَ) ve sevfe (سَوْْفَ) edatları gibi hazif veya istibdâl yoluyla dâhil oldukları yapıdan ayrılabilen (الإنْفِصَال بِالحذفْف أَوْ الإستنِبْدَال) ancak tek başlarına kullanılamayan (غَيْر قَابِلَة لِِلْنِنِفَراد) anlambirimlerdir. Bunlar nahiv bilginlerine göre kelimedir. Nitekim Sîbeveyhi kitabında kelimelerin harf sayılarına ilişkin başlıkta ${ }^{32}$ hurûfu'l-me ânî ve zamirler gibi tek harften oluşan kelimeleri ( أَقَُّ (مَا تَكُونُ عَلَيْهِ الحَكَلمَةُة حَرْفُ وَاحِد melere geçmiştir. Abdurrahmân el-Hâc Sâlih'e göre bu anlamda nisbe yâ'sı ve te'nîs tâ'sı da birer kelimedirler. Sîbeveyhi bu ikisini mazmûme (المَضْمُومَةَ) olarak nitelendirmiştir. Ancak bu ikisi bir kelimenin kuruluşunda zorunlu olarak yer almayan kelimelerdir. Nitekim bunlar bitiștiği kelimeden ayrılabilmekte ve söz konusu kelimenin varlığı devam etmektedir. ${ }^{33}$ Dolayısıyla kelime tanımı için getirilen biçimsel/lafzî ölçüt, ayrı olarak bulunabilme (الإنْفِصَال) ölçütüdür ve Abdurrahmân el-Hâc Sâlih'e göre nesnellik ve objektiflik özelliklerine sahiptir. ${ }^{34}$

Söz konusu tasniften yola çıkan Abdurrahmân el-Hâc Sâlih, morfem yani telaffuz edilebilen en küçük anlamlı birim kavramıyla kelime kavramının her zaman

${ }^{31}$ Abdurrahmân el-Hâc Sâlih, "el-Medrasetu'l-Halîliyyetu'l-Hadîse ve'd-Dirâsâtu'l-Lisâniyyetu'l-Hâliyye fi'l-'Âlemi'l-'Ârabî”, 39-40.

32 İlgili başllk (بَابُ عِدَّة مَا يَكُونُ عَلَيْهِ الكَلِمِ için bk. Sîbeveyhi, el-Kitâb, 4/216. Sîbeveyhi'nin bu yaklaşımı kendisinden sonra telif edilen hurûfu'l-mecânî kitaplarında da görülmektedir. Örneğin Murâdî, bu kelimeleri uhâdî, sunâî, sulâsî, rubâî̀ ve humâsî olarak tasnif etmiștir. Bk. Bedruddîn el-Hasen b. Kâsım el-Murâdî, el-Cene'd-Dânî fî Hurûfi'l-Me ânî, thk. Fahruddîn Kabâve-Nedim Fâdıl (Beyrut: Dâru'l-Kutubi'l-'Illmiyye, 1992)

33 Abdurrahmân el-Hâc Sâlih, "Mukaddime", 8; Abdurrahmân el-Hâc Sâlih, "el-Medrasetu'l-Halîliyyetu'lHadîse ve'd-Dirâsâtu'l-Lisâniyyetu'l-Hâliyye fi'l-'Âlemi'l-'Ârabî", 34-35; Abdurrahmân el-Hâc Sâlih, Buhûs ve Dirâsât fi'l-Lisâniyyâti'l-'Arabiyye, 2/83-84.

${ }^{34}$ Abdurrahmân el-Hâc Sâlih, el-Bune'n-Nahviyyetu'l- 'Arabiyye (Cezayir: Menşûrâtu'l-Mecme'i'l-Cezâîrî li'l-Lugati'l-'Arabiyye, 2016), 37. 
örtüşmediğini belirtir. Zira harf-i cerler gibi üçüncü grupta yer alan anlambirimler nahiv bilginlerine göre kelime olarak kabul edilirlerken ifti'âl sıygasındaki tâ veya muzâraat harfleri gibi birinci grupta yer alan anlambirimler kelime olarak kabul edilmezler. Zira harf-i cer dâhil olduğu kelimeden çıkarıldığında kelime yalnız başına kullanılmaya devam etmektedir. Ancak ifti'âl sıygasındaki tâ veya muzâraat harfi içinde bulunduğu kelimeden çıkarıldığında kelime infirad özelliğini kaybetmektedir. Dolayısıyla ifti'âl sıygasındaki tâ ve muzâraat harfleri gibi anlambirimler kelime değil kelimenin parçasıdır. Harf-i cer ve harf-i ta'rîf gibi anlambirimler ise birer kelime olarak Abdrurrahmân el-Hâc Sâlih'in lafza (اللَّفْظَة) olarak adlandırdığı yapının parçasıdırlar. ${ }^{35}$

\subsection{Lafza ve İnfirad}

Abdrurahmân el-Hâc Sâlih, infirad kavramiyla Halîl b. Ahmed'in ifadelerinden hareketle "konuşma olayında kullanılabilen en küçük birimlerin" sahip olduğu özelliği kastetmektedir. Bu, Abdrurahmân el-Hâc Sâlih'in anlambirimler için yaptığl tasnifteki kitâb (كَتِّاب) ve menzil (مَنِْ gibi ikinci grupta yer alan müfred kelimelerin sahip olduğu bir özelliktir. Nitekim bu kelimeler, hem ayrı olarak bulunabilen (الانفصال التام) hem de tek başlarına kullanılabilen (قابلة للانفر اد) kelimelerdir. Sîbeveyhi

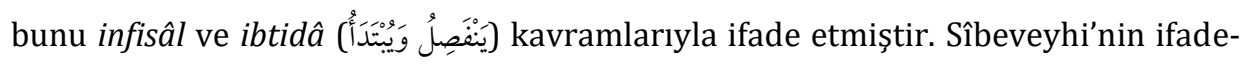

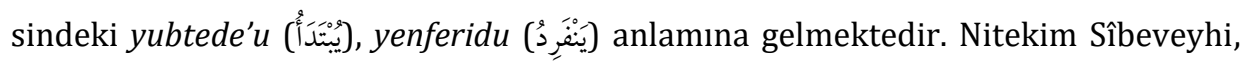

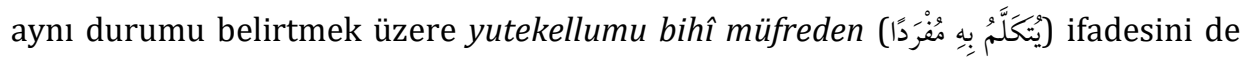
kullanmaktadır. ${ }^{36}$

"Nahiv bilginlerinin hareket noktası "tek başına yargı bildiren bir söz (كَلام مُفِيد)

oluşturabilen en küçük birim" olarak ortaya çıkar. Bu, konuşma olayında bağımsız olarak kullanılabilen en küçük ögeyi ifade eder. Böylece araştırmacı, söz konusu ögenin yargı bildiren bir söz olmanın yanında bir dilsel birim olduğunu da ortaya koymuş olur. Örneğin "Bu nedir?" sorusunun cevabı olarak söylenen "Kitap." ifadesi böyledir."37

Harf-i ta'rîf, harf-i cerler, muttasıl zamirler, sîn ve sevfe gibi üçüncü grupta yer alan anlambirimler ise kitâb ve menzil gibi müfred kelimelerden farklıdır. Bunlar dâhil oldukları yapıdan ayrılabilen ancak tek başlarına kullanılamayan kelimelerdir. Dolayısıyla bu kelimeler, infirad özelliğine sahip olmayıp bu özelliğe sahip olan kelimelere eklenmektedirler.

"Bu așamadan sonra araştırmacl, söz konusu ögenin (infirad özelliğine sahip kelimenin) önüne veya sonuna eklenebilen ancak onu müfred bir isim olmaktan çıkarmayan birimlerin neler olduğuna bakar. Bu birimler sayesinde her ögenin be-

35 Abdurrahmân el-Hâc Sâlih, “el-Medrasetu'l-Halîliyyetu'l-Hadîse ve'd-Dirâsâtu'l-Lisâniyyetu'l-Hâliyye fi'l-'Âlemi'l-'Ârabî”, 34-35, 78.

36 Sîbeveyhi, el-Kitâb, 1/187; Abdurrahmân el-Hâc Sâlih, "Mukaddime", 8; Abdurrahmân el-Hâc Sâlih, “el-Medrasetu'l-Halîliyyetu'l-Hadîse ve'd-Dirâsâtu'l-Lisâniyyetu'l-Hâliyye fi'l-'Âlemi'l-'Ârabî", 32, 74.

${ }^{37}$ Abdurrahmân el-Hâc Sâlih, "en-Nahvu'l-'Arabî ve'l-Bineviyye”, 214. 
lirli bir cümle içinde elde ettiği konum ve yerine getirdiği işlev belirlenmiș olur. Mümkün konum ve işlevlerin toplamı ise kelimenin lafzî (biçimsel) tanımını oluşturur. Ancak bu tanım müfred kelimeye ait bir tanım olmaktan çok tüm ekleriyle birlikte bir bütün teşkil eden kelimeye aittir. Bu yüzden biz bunu adlandırmak üzere Radıyyuddîn el-Esterâbâdî'nin [ö. 688/1289] kelimeden büyük ama sözden küçük birimler için kullandığı "lafza" [اللَّفَّْة] (isim veya fiil) terimini tercih ediyoruz." 38

Abdurrahmân el-Hâc Sâlih'in ifadelerinden anlaşıldığı üzere lafza, kelime düzeyini aşmaktadır. Buna göre lafza, önünde veya sonunda birtakım ekler (زوائد) bulunan el-kitâb (الكِتَاب) ve kumtu (قُمْنُ) gibi isim veya fiil türünden ifadelere işaret etmektedir. Buna göre el-kitâb, "lafza ismiyye", kumtu ise "lafza ficliyye"dir. Dolayısıyla kelime lafzayı oluşturan bir birim olarak ortaya çıkmaktadır. ${ }^{39}$ Abdurrahmân el-Hâc Sâlih'in anlambirimler için yaptığı tasnif açısından gerek el-kitâb gerekse de kumtu ifadeleri birer lafza olarak iki kelimeden oluşmaktadır.

Abdrurahmân el-Hâc Sâlih lafza terimini İbn Ya îș (ö. 643/1245) ve Radî elEsterâbâbâdı̂’nin (ö. 688/1289) kullandıklarını belirtir. ${ }^{40}$ Lafza sözcükten (الكلمة) büyük ve sözden (الكلام) küçük yapıları anlatmaktadır. ${ }^{41}$ Buna göre el-kitâb ifadesi bir lafza olarak زَيْدُ مُنْطَلِقِ cümlesinden küçük ve kendisini oluşturan el (ال) ve kitâb (كِتَاب) kelimelerinden büyüktür. Bununla birlikte bazen bir lafza aynı zamanda yar-

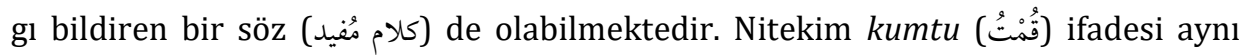
zamanda hem bir lafza hem de bir sözdür. ${ }^{42}$ Abdrurahmân el-Hâc Sâlih'e göre;

"Nahiv bilginleri isim ve fiilin tanımını bunların önüne veya sonuna eklenebilen bazı birimleri dikkate alarak yaparlar. Bu, kelimeyi aşan bir düzeydir. Nitekim isim veya fiil için geliştirilen tanım ile müfred kelimeye ait tanım arasındaki fark, birincisinde aralarında dilsel birliktelikler kurmaları mümkün olmayan, aksine Halîl b. Ahmed'in de belirttiği gibi müfred bir isim veya fiile eklenip çlkarılabilen ve bu yönüyle de yalnızca bağlaç işlevine sahip ögelere yer verilmesidir. İsim için

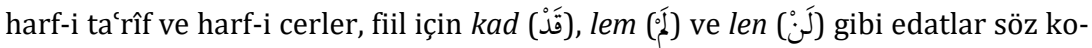
nusu ögelere örnek olarak gösterilebilir." ${ }^{43}$

Abdrurahmân el-Hâc Sâlih, Fransız dilbilimci Jean Gagnepain'ın (ö. 2006) müfred kelime ile lafza arasındaki ayrımın farkına vardığını ve Amerikalı dilbilim-

38 Abdurrahmân el-Hâc Sâlih, “en-Nahvu'l-'Arabî ve'l-Bineviyye”, 214-215.

39 Abdurrahmân el-Hâc Sâlih, "el-Medrasetu'l-Halîliyyetu'l-Hadîse ve'd-Dirâsâtu'l-Lisâniyyetu'l-Hâliyye fi'l-‘Âlemi'l-'Ârabî”, 32, 34; Abdurrahmân el-Hâc Sâlih, Buhûs ve Dirâsât fi'l-Lisâniyyâti'l-'Arabiyye, $2 / 50$.

40 Abdurrahmân el-Hâc Sâlih, "en-Nahvu'l-'Arabî ve'l-Bineviyye”, 215; Abdurrahmân el-Hâc Sâlih, "elMedrasetu'l-Halîliyyetu'l-Hadîse ～ve'd-Dirâsâtu'l-Lisâniyyetu'l-Hâliyye ～fi'l-'Âlemi'l- 'Ârabî”, 32; Abdurrahmân el-Hâc Sâlih, Buhûs ve Dirâsât fi'l-Lisâniyyâti'l-'Arabiyye, 2/50.

41 Abdurrahmân el-Hâc Sâlih, Buhûs ve Dirâsât fi'l-Lisâniyyâti'l-'Arabiyye, 2/49.

42 Abdurrahmân el-Hâc Sâlih, "en-Nahvu'l-'Arabî ve'l-Bineviyye”, 215.

43 Abdurrahmân el-Hâc Sâlih, “en-Nahvu'l-'Arabî ve'l-Bineviyye”, 214. 
cilerin cümlenin morfemlerin bir araya gelmesiyle değil, morfemleri ihtiva eden öbeklerin (lafza terimine işaret) bir araya gelmesiyle oluştuğuna dikkat çektiklerini belirtir. ${ }^{4}$ Ona göre gerek modern dilbilim gerekse geç dönem nahiv çalışmalarında Halîl ve Sîbeveyhi'de görülen söz konusu ayrım bulunmamaktadır. Söz konusu ayrıma göre cümleyi olușturan mübtedâ, haber, fiil, mef ûl gibi kategoriler müfred kelimeleri değil, içinde müfred kelimeleri de barındıran lafzaları ihtiva eder. Buna göre müfred bir kelime olan kitâb (كِّelimesi; asıl/çekirdek olarak kabul edilmekte ve önüne harf-i ta'rîf ve harf-i cer, sonuna i'râb alameti, tenvîn, muzâfun ileyh ve sıfat gibi birimlerin eklenmesiyle cümle içinde bir lafza olarak mübtedâ, haber, fâil, mef ûl gibi işlevleri yüklenebilmektedir. ${ }^{45}$ Abdurrahmân elHâc Sâlih'in bu ifadelerinden lafza teriminin izâfet ve sıfat terkiplerini de kapsadığı anlaşılmaktadır. Nitekim her iki terkip de kelimeden büyük ve sözden küçük yapılardır. Abdrurahmân el-Hâc Sâlih, kitâb (كَتَب) kelimesi üzerinden tanımladığı lafza örneklerini şu şekilde göstermiştir: ${ }^{46}$

\begin{tabular}{|c|c|c|c|c|c|c|c|}
\hline & & & \# & كِتاب & \# & & \\
\hline & & & $\#$ & كِتاب & ال & $\#$ & \\
\hline \# & مُفِيد & ن & $\therefore$ & كِتاب & - & \# & \\
\hline \# & هذا & زيدٍ & $\therefore$ & كِتاب & - & $\#$ & \\
\hline \# & المُفِيد & زيدٍ & 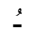 & كِتاب & - & $\#$ & \\
\hline$\#$ & المُفِيد & - & $=$ & كِتاب & ال & 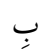 & \# \\
\hline$\#$ & الذي هو هنا & زيدٍ & $=$ & كِتاب & - & ب & \# \\
\hline
\end{tabular}

\subsection{Mevdı` ve Misâl}

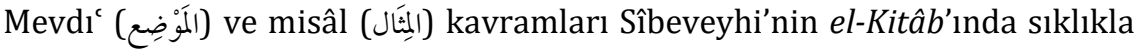
geçmektedir. Abdurrahmân el-Hâc Sâlih'e göre bu kavramlar, nahiv öğretiminde kullanıldığı şekilde "nahiv kuralı" anlamına gelmemektedir. ${ }^{47}$

Abdurrahmân el-Hâc Sâlih'e göre mevdı', anlambirimlerin lafza veya terkip içinde işgal ettiği yerleri gösterir. Bu yerler basamak veya bölme olarak düşünülebilir. Asıl konumundaki çekirdek kelimeye tedricî olarak birimler eklenir. Ekleme (ziyâde) işlemi bu düzeyde dönüștürümü (tahvil) ifade eder. Nahiv bilginleri bunu

44 Abdurrahmân el-Hâc Sâlih, "en-Nahvu'l-'Arabî ve'l-Bineviyye", 214. Abdurrahmân el-Hâc Sâlih lafza terimi için Fransızca "lexie" terimini önermiștir. Bk. Abdurrahmân el-Hâc Sâlih, "el-Medrasetu'lHalîliyyetu'l-Hadîse ve'd-Dirâsâtu'l-Lisâniyyetu'l-Hâliyye fi'l-'Âlemi'l-'Ârabî”, 32. Lexie terimi bazı modern dilbilim sözlüklerinde İngilizce lexical unit veya multi-word lexical unity, Türkçede ise sözlüksel birim terimiyle karşılanmakta ve birden fazla kelimeden oluşan ve sözlükbirim, türev, bileşik biçim gibi farklı boyuttaki birimlere verilen ortak ad olarak tanımlanmaktadır. Bk. Ramzi Munir Baalbaki, Dictionary of Linguistic Terms (Beirut: Dar El-Ilm Lilmalayin, 1990), 321; Berke Vardar, Açıklamalı Dilbilim Terimleri Sözlüğü (İstanbul: Multilingual Yabancı Dil Yayınları, 2002), 185.

${ }^{45}$ Abdurrahmân el-Hâc Sâlih, Buhûs ve Dirâsât fi'l-Lisâniyyâti'l-'Arabiyye, 2/9, 49.

${ }^{46}$ Abdurrahmân el-Hâc Sâlih, "el-Medrasetu'l-Halîliyyetu'l-Hadîse ve'd-Dirâsâtu'l-Lisâniyyetu'l-Hâliyye fi'l-'Âlemi'l-'Ârabî", 33.

${ }^{47}$ Abdurrahmân el-Hâc Sâlih, Buhûs ve Dirâsât fi'l-Lisâniyyâti'l-'Arabiyye, 2/49-50. 


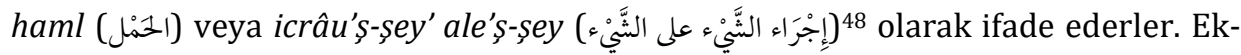
leme işlemleri sonucunda lafzayı üreten soyut kalıp (المِثال المُوَلِّد لِلَّفْظَة) ortaya çlkar. Abdurrahmân el-Hâc Sâlih bu soyut kalıba misâl ${ }^{49}$ adının verildiğini vurgular. Burada ekleme işleminin tersi de söz konusudur. Yani eklenen birimler çlkarlarak asıl konumundaki müfred kelimeye ulaşılabilir. Nahiv bilginleri buna asla döndür-

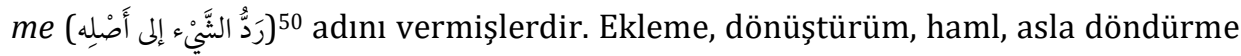
gibi adlandırmalar yapılan bu işlemler neticesinde her bir unsurun misâl içindeki mevdı'ı belirlenmiş olur. Çekirdek kelimenin etrafındaki basamak, hane veya bölmeleri ifade eden mevdı' bazen boş olabilir. Zira mevdı', mevdı'ın içinde yer alan birimin kendisi değildir. Nahiv bilginleri bunu söz konusu birimlerin eklenip çıka-

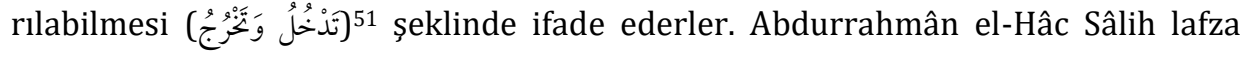
düzeyindeki ekleme işleminin binâ (الِْنَاء) kavramılla değil vasl (الوَصْل) kavramıyla ifade edildiğini vurgular. Zira binâ kelimeye ilişkin bir terimken vasl lafzaya ilişkindir. Buna göre örneğin ifticâl sıygasındaki tâ ve muzâraat harfleri gibi birimlerin herhangi bir kelimenin yapısı içinde yer alması binâ kavramıyla ifade edilirken harf-i ta'rîf ve harf-i cerler gibi birimlerin bir lafza içinde yer almaları vasl kavramiyla ifade edilmektedir. ${ }^{52}$

Mevdı', her parçanın bütün içinde -kendine özgü vaz'î işlevini yerine getirdiği- özel konuma; misâl ise bu konumların toplamı mesabesindeki soyut kalıba işaret etmektedir. ${ }^{53}$ Buna göre lafza düzeyinde kitâb kelimesi etrafında altı mevdıc bulunmakta ve bu altı mevdı`ın toplamı misâli oluşturmaktadır: ${ }^{54}$

48 Örnek olarak bk. Sîbeveyhi, el-Kitâb, 2/264, 411; 4/300, 361-362; Ebu'l-Abbâs Muhammed b. Yezîd el-Müberred, el-Muktedab, thk. Muhammed Abdulhâlik 'Uzayme (Kahire: 1994), 2/100, 311; Ebu'lFeth Osmân İbn Cinnî, el-Hasâis, thk. Muhamed Ali en-Neccâr (Kahire: el-Hey'etu'l-'Âmme li Kusûri'sSekâfe, 2006), 1/65, 341; 2/483.

49 Nahiv bilginleri misâl kavramı yerine had (الحَدَ) ve bâb (البَاب) kavramlarını da kullanmışlardır. Bk.

Abdurrahmân el-Hâc Sâlih, Buhûs ve Dirâsât fi'l-Lisâniyyâti'l-'Arabiyye, 2/9. Abdurrahmân el-Hâc Sâlih, nahiv bilginlerinin bazen aynı müsemmâyı belirtmek üzere misâl kavramı yerine binâ kavramını da kullandıklarını, bununla birlikte misâl kavramının binâ kavramından farklı olarak dilde kullanımı olmayan ve temsil kabilinden üretilen dilsel yapıları da kapsadığını vurgular. Ona göre Sîbeveyhi'nin "Bu bir temsildir ancak dilde kullanımı yoktur.” ifadesiyle İbn Cinnî’nin dehale (دَخَلَ)

fiilinden türetilen dehanlele (دَخَنْلَ) fiiliyle ilgili olarak “Buradaki temsil, dilde kullanımı olmayan bir türetimden ibarettir." şeklindeki ifadesi, misâl kavramının dilsel yapılar için bir model ve simülasyon mesabesindeki temsil kavramını da içine aldığını göstermektedir. Bk. Sîbeveyhi, el-Kitâb, 1/374; İbn Cinnî, el-Hasâis, 3/97; Abdurrahmân el-Hâc Sâlih, Mantıku'l-'Arab fí 'Ulûmi'l-Lisân (Cezayir: elMuessesetu'l-Vataniyye li'l-Funûni'l-Matba'iyye, 2012), 279-282.

50 Örnek olarak bk. Sîbeveyhi, el-Kitâb, 2/229; 3/361; Müberred, el-Muktedab, 1/387; Sîrâfî, Şerhu Kitâbi Sîbeveyhi, 5/245.

51 Abdurrahmân el-Hâc Sâlih, Buhûs ve Dirâsât fi'l-Lisâniyyâti'l-'Arabiyye, 2/13.

52 Abdurrahmân el-Hâc Sâlih, “el-Medrasetu'l-Halîliyyetu'l-Hadîse ve'd-Dirâsâtu'l-Lisâniyyetu'l-Hâliyye fi'l-'Âlemi'l-'Ârabî”, 35-36; Abdurrahmân el-Hâc Sâlih, el-Bune'n-Nahviyyetu'l-'Arabiyye, 95.

53 Abdurrahmân el-Hâc Sâlih, "en-Nahvu'l-‘Arabî ve'l-Bineviyye”, 213.

${ }^{54}$ Abdurrahmân el-Hâc Sâlih, Buhûs ve Dirâsât fi'l-Lisâniyyâti'l-'Arabiyye, 2/13-14. 


\begin{tabular}{|c|c|c|c|c|c|}
\hline الصفة & 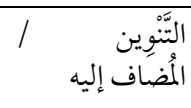 & علامة الإعراب & النَّ اة الإسْمِيَّة & أداة التعريف & حروف الجر \\
\hline 3 & 2 & 1 & 0 (كِتاب) & 1 & 2 \\
\hline
\end{tabular}

Kitâb müfred ismi üzerine eklenen farklı anlambirimler sayesinde el-kitâb (الكِتِاب), bill-kitâb (كبالكِتِاب), kitâbu Zeyd (كِتاب زَيْد), kitâbun mufíd (كِتابُ مفيد) gibi lafza örnekleri elde edilebilmektedir. Abdurrahmân el-Hâc Sâlih'e göre cümle anlambirimlerden değil, anlambirimleri barındıran lafzalardan oluşmaktadır. ${ }^{55}$

Misâl; lafza düzeyinde olduğu gibi lafzadan daha küçük olan kelime ${ }^{56}$ ve ondan daha büyük olan cümle ${ }^{57}$ düzeylerinde de ortaya çıkmaktadır. Örneğin Arapçada ism-i mekân grubuna ait kelimelerin bu düzeydeki misâlleri bir tür yapı olarak değerlendirilir. Bununla, sözcüğü oluşturan parçaların belirli bir kalıba göre bir araya getirilmesi kastedilir. Dolayısıyla herhangi bir eksilti, sözcüğün yapısının kaybolmasına yol açar. Dilin bu düzeyine ait haml işlemleri, şu şekilde gösterilir: ${ }^{58}$

\begin{tabular}{|c|c|c|c|c|}
\hline \multirow{7}{*}{$\begin{array}{l}\text { ․․․ } \\
\text { : }\end{array}$} & b & 5 & s & \multirow{7}{*}{$\begin{array}{l}\text { mef al (مَفْعَ) ve mef'il (مَفِعِلَ) } \rightarrow \\
\text { bu sözcükleri bir araya getiren } \\
\text { ortak kalıp (misâl). }\end{array}$} \\
\hline & Fetha & Fetha & Fetha & \\
\hline & ج & J & 5) & \\
\hline & Sükûn & Sükûn & Sükûn & \\
\hline & J & $\varepsilon$ & ت & \\
\hline & Kesra & Fetha & Fetha & \\
\hline & س - ل س & ب & ب & \\
\hline & & \multicolumn{2}{|l|}{ Eș değerlilik } & \\
\hline
\end{tabular}

Söz konusu soyut kalıp (misâl) asıl olarak kabul edilmekte ve bu asıldan hareketle sınırsız sayıda fer cüretilebilmektedir. Abdurrahmân el-Hâc Sâlih misâl kavramı için Fransızca schème générateur ve İngilizce generator pattern terimlerini önermiştir. Ona göre Arap grameri kelime, lafza ve cümle düzeylerinde tümüyle

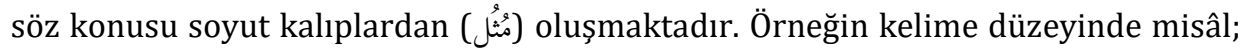
onun binâsı, vezni ve sıygası durumundadır. Bu soyut yapıda değişkenler fâ-'ayn-

55 Abdurrahmân el-Hâc Sâlih, Buhûs ve Dirâsât fi'l-Lisâniyyâti'l-'Arabiyye, 2/73.

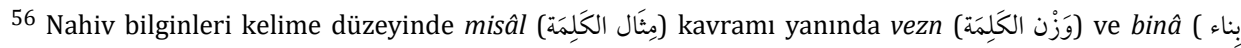
(الكَلِمَة kavramlarını da kullanmışlardır. Bk. Abdurrahmân el-Hâc Sâlih, Buhûs ve Dirâsât fi'lLisâniyyâti'l-'Arabiyye, 2/21, 48.

57 Misâl'in cümle düzeyindeki belirlenimi çalışmanın "âmil” başlığında ayrıntılı olarak ele alınmıștır.

58 Abdurrahmân el-Hâc Sâlih, “en-Nahvu'l-‘Arabî ve'l-Bineviyye”, 213. 
lâm ( ) simgeleriyle gösterilmekte, sabit unsurlar ise olduğu gibi bırakılmaktadır. Bunlar kelime düzeyinde misâli oluşturan soyut mevdı́lardır (fâ mevdı́ı, 'ayn mevdı́ı ve lâm mevdı'ı). Dolayısıyla bu mevd'ılar bazen boş olabilmektedir. Örneğin vefâ (وَفَف) fiilinin emr-i hâzırı olan fi (فِى) kelimesinde fâ ve lâm mevdı́ları

boştur. Lafza düzeyinde mevdı'ın boş olmasıyla kelime düzeyinde boş olması arasında fark vardır. Buna göre lafza düzeyinde mevdı́ın boş olması mütekellimin seçimine bağlıyken ${ }^{59}$ kelime düzeyinde mevdı`ın boş olması zorunlu bir durumdur. Sîbeveyhi'nin el-Kitâb'ında kelime düzeyinde üç yüze yakın misâl (vezn/binâ) yer almaktadır. Daha sonraki çalışmalarda Arap dilinde ekseriyeti çok az kullanılan 1200'den fazla misâl tespit edilmiștir. ${ }^{60}$

Abdurrahmân el-Hâc Sâlih'e göre Halîl b. Ahmed tasrif alanında önemli matematiksel çıkarımlar ve tespitler yapmıştır. Buna göre Arap dilinde kelime, anlam belirleyici iki unsurdan oluşur. Bunlardan ilki kelimenin kökü (مَادَّة أَصَلِيَّة), diğeri ise binâsı ve veznidir. Kelime kökleri üçten beșe kadar harften oluşmaktadır. Halîl buradan hareketle Arap dilindeki kelimelerin dökümünü yapmak istemiş ve iki harfli, üç harfli kelimelerden başlayıp beş harften oluşan köklere kadar bir sıralama yapmiştır: 61

“İkili kelimeler iki şekilde tasrif edilir: kad (قَّ) ve dak (دَقْ) gibi. Üçlü kelimeler altı şekilde tasrif edilir: darabe (ضرب), dabera (ضبرض), bedara (ضضر), radabe (رضب) ve rabeda (ربض) gibi. Dörtlü kelimeler 24 şekilde tasrif edilir... Beşli kelimeler 120 şekilde. Bunlardan müsta'mel ve mühmel olanlar tespit edilir." 62

Kelime düzeyinde misâl için Halîl ve Sîbeveyhi, kelimeyi oluşturan harfleri muhtevadan soyutlamışlar ve her bir harf için fâ-'ayn-lâm simgelerini belirlemişlerdir. Radî el-Esterâbâdî buradan hareketle fâ-'ayn-lâm simgeleriyle ilgili olarak sülâsî mücerredler için şu ifadeleri kullanmıștır: "Son harf olan lâm, i'râb ve binâ ile ilgili olduğu için kelimenin veznine ait değildir. Dolayısıyla on iki vezin ortaya çıkar. Çünkü fâ için üç hareke, ayn için ise üç hareke ve sükûn mümkündür. Bu on iki vezin-

${ }^{59}$ Mütekellim el-kitâb (الكِتِاب) yerine kitâb (كِتاب)'ı tercih edebilir.

60 Abdurrahmân el-Hâc Sâlih, “en-Nahvu'l-'Arabî ve'l-Bineviyye”, 213-214; Abdurrahmân el-Hâc Sâlih, “el-Medrasetu'l-Halîliyyetu'l-Hadîse ve Meşâkilu 'İlâci'l-‘Arabiyye bi'l-Hâsûb”, 77-78; Abdurrahmân el-Hâc Sâlih, Buhûs ve Dirâsât fi'l-Lisâniyyâti'l-'Arabiyye, 2/14-15, 17.

61 Abdurrahmân el-Hâc Sâlih, Buhûs ve Dirâsât fi'l-Lisâniyyâti'l-'Arabiyye, 2/68-69. İbn Cinnî’nin kâme (قَامَ) fiili üzerinden yaptığı tasnifte kelimenin kökünün delaletini lafzî delalet, binasının delaletini ise sınâî delalet olarak adlandırır. Buna göre kâme fiilinin lafzı, ayağa kalkma eylemine, binâsı ise mazi fiil olduğuna delalet etmektedir. Bk. İbn Cinnî, el-Hasâis, 3/98; Abdurrahmân el-Hâc Sâlih, el-Bune'nNahviyyetu'l-'Arabiyye, 44.

62 el-Halîl b. Ahmed el-Ferâhîdî, Kitâbu'l-'Ayn, thk. Mehdî el-Mahzûmî-İbrahim es-Sâmerrâî (Beyrut: Mektebetu'l-Hilâl), 1/59. Halîl b. Ahmed, dörtlü kelimeler için 'akrab (عقرب), 'abrak (عبرق), 'akber (عقبر), 'abkar (عبقر)... örneklerini ve beşli kelimeler için sefercel (سفرجل), seferlec (سفرلج), sefecrel (سفجرل), secefrel (سجفرل)... örneklerini vermektedir. Bk. el-Halîl b. Ahmed, Kitâbu'l-'Ayn, 1/59. 


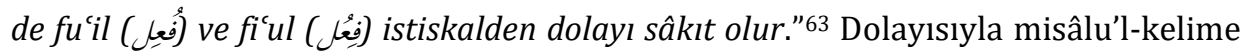
düzeyinde sülâsî mücerredler şeması şu şekildedir:64

\begin{tabular}{|c|c|c|c|c|}
\hline سكون & كسرة & ضمة & فتحة & \\
\hline فَعْل & فَعِل & فَعُل & فَعَل & \multirow[t]{2}{*}{ فتحة } \\
\hline فَلْس & كَتِف & عَضُد & فَرَس & \\
\hline فُغْل & فُعِل & فُعل & فُعَلَ & \multirow[t]{2}{*}{ ضمة } \\
\hline قُفْلْ & - & عُنْق & صُرَد & \\
\hline فِعْل & فِعِل & فِعُلْ & فِعَلَ & \multirow[t]{2}{*}{ كسرة } \\
\hline حِبْر & إبِل & - & عِنَب & \\
\hline
\end{tabular}

Abdurrahmân el-Hâc Sâlih kelime ve lafza düzeyindeki mevdılar ile cümle düzeyindeki mevdı`lar arasında şöyle bir farka işaret etmektedir. Mevdı`da yer alan birimler cümle düzeyinde takdim veya tehir edilebilmektedir. $\mathrm{Bu}$, lafza ve kelime düzeyinde mümkün değildir. Özetle misâl, belirli bir tertibe göre sıralanmış itibarî mevdıllar bütünü olarak tanımlanabilir. ${ }^{65}$

Mevdı` ile ilgili bir başka husus, onun dilsel birimin türünü (isim, fiil, harf) ve hükmünü bilmek/belirlemek için kullanılan bir ölçüt (mikyas) olmasıdır.66 Abdurrahmân el-Hâc Sâlih'e göre Sîbeveyhi ve Müberred (ö. 286/900) gibi isimlerin ifadelerinden şu sonuç ortaya çıkmaktadır: "Her dilsel birimin kelam içinde kendisine özgü bir mevdı'ı vardır. Bunun dışında bir mevdı'a konulduğunda ya kelam

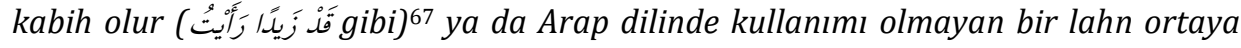

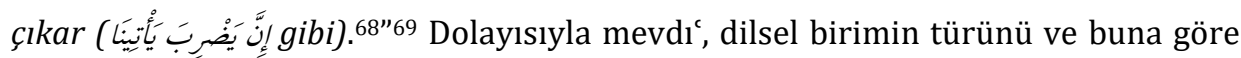
ortaya çıkan hükmü belirlemiş olmaktadır. Muzâri fiilin, isme olan benzerliğine rağmen, inne (إَِّّ) edatından sonra gelemeyişi buna örnek olarak gösterilebilir. Nahiv bilginleri bu durumu haddu'l-kelâm (حَدّ الكَلام) ve aslu'l-kelâm (أَصْل الخَلام) olarak adlandırmışlardır. ${ }^{70}$

Abdurrahmân el-Hâc Sâlih'e göre bir dilsel birimin mevdı'ı, onun mevcut konuşma olayında bulunduğu yer demek değildir. Bu ikisi birbirinden farklı şey-

63 Radiyyuddîn el-Esterâbâdî, Şerhu Şâfiyeti İbni'l-Hâcib, thk. Muhammed Nûr el-Hasen vd. (Beyrut: Dâru'l-Kutubi'l-'Illmiyye, 1982), 1/35.

${ }^{64}$ Abdurrahmân el-Hâc Sâlih, Buhûs ve Dirâsât fi'l-Lisâniyyâti'l-'Arabiyye, 2/72.

65 Abdurrahmân el-Hâc Sâlih, Buhûs ve Dirâsât fi'l-Lisâniyyâti'l-'Arabiyye, 2/15-16. Mevdı'in kelime, lafza ve cümle düzeylerini așan ve hitâb alanına ait istifham, şart, emir ve haber kiplerini ilgilendiren bir düzeyi daha bulunmaktadır. bk. Abdurrahmân el-Hâc Sâlih, Buhûs ve Dirâsât fi'l-Lisâniyyâti'l'Arabiyye, 2/16.

${ }^{66}$ Abdurrahmân el-Hâc Sâlih, Buhûs ve Dirâsât fi'l-Lisâniyyâti'l-'Arabiyye, 2/10.

67 Sîbeveyhi, el-Kitâb, 1/26.

68 Sîbeveyhi, el-Kitâb, 1/14.

${ }^{69}$ Abdurrahmân el-Hâc Sâlih, Buhûs ve Dirâsât fi'l-Lisâniyyâti'l-'Arabiyye, 2/10.

${ }^{70}$ Abdurrahmân el-Hâc Sâlih, Buhûs ve Dirâsât fi'l-Lisâniyyâti'l-'Arabiyye, 2/10-11. 


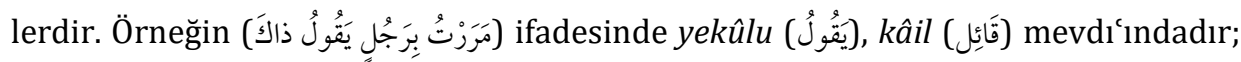
ancak i'râbı onun i'râbından farklıdır. Hatta bir dilsel birim aynı ifadede birden fazla mevdı sahibi olabilmektedir. Örneğin men (مَن) edatı aynı ifade içinde istifhâm veya şart olarak yorumlanabilmektedir. Abdurrahmân el-Hâc Sâlih'e göre nahiv bilginlerinin dilsel birimin konuşma olayında bulunduğu yer (mevki) ile onun mevdı'ını birbirinden ayırmış olmaları bir soyutlama becerisinin göstergesidir. Nahiv bilginlerinin bu şekilde mevcut mevki ile soyut mevdı` arasında bir ayrım yaptıklarının delili, dilsel birimin mevcut haliyle olması gereken hali arasında kesin bir ayrım yapmış olmalarıdır. Dolayısıyla lafız ve mevdı` arasında mutabakat olabildiği gibi bunun aksi de söz konusudur. Lafız mevdı'a muhalif olarak geldiğinde nahiv bilginleri bunun nedenini araştırmaktadırlar. Sîbeveyhi'nin kable ve ba'de kelimeleriyle ilgili şu ifadeleri söz konusu ayrımı ortaya koymaktadır: "Bu iki kelime, lafzen merfû oldukları halde nasb veya cer mevdı'ında bulunabilirler. Nitekim bunları muzâf olarak kullandığında asıl hallerine döndürmüş olursun."71 Abdurrahmân el-Hâc Sâlih bu işlemi haml olarak adlandırır ve bunun nahiv eserlerinde sıklıkla kullanıldığını belirtir. ${ }^{72}$

Nahiv bilginleri açısından mevdı'ın dilsel birimin bulunduğu mevki olmayıp soyut bir konum olduğunu gösteren bu husus, dilsel birim takdim veya tehir edildiğinde mevdı́ın değișmemesidir. Abdurrahmân el-Hâc Sâlih, bu durumu fâil ve mef ûlün fiil ile olan ilişkisi üzerinden ortaya koymuştur. Buna göre fâilin fiilden sonra yer alması zorunludur. 0 halde fâilin Arap dilinde tek mevkii vardır ve fâilin mevdı'ı ile mevkii birdir, denilebilir. Benzer bir durum harf-i cerlerin ve harf-i tari-

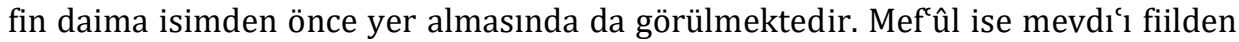
sonra olmasına rağmen fiiline takdim edilebilmekte ve farklı bir mevkide bulunabilmektedir. Örneğin ضَرَبْتُ زَيْدًا ve زَيْدًا ضَرَبْتُ cümlelerinde “Zeyden" kelimesinin mevkileri farklı olmasına rağmen mevdıcları aynıdır. ${ }^{73}$ Mevdı ${ }^{c}-m e v k i$ ayrımına dair bir başka husus, nahiv bilginlerinin mevdı'ın boş olabileceğine ilişkin ifadeleridir. Örneğin كَا هذا؟ sorusunun cevabı olarak kullanılan كِتاب ifadesinde üç mevdı` vardır. Birincisi ibtidâ mevdı`ı, ikincisi mübtedâ mevdı`ı ve üçüncüsü haber mevdı`ıdır. Söz konusu cevapta bunlardan sadece haber mevdı'inda bir dilsel birim (كَتَاب) bulunmaktadır. Dolayısıyla mübtedâ mevdı`ında هذا هelimesi ve onun önünde de muktezâ-i hâle göre إِ li $_{\text {kelimesi de gelebilmektedir. }}{ }^{74}$

\begin{tabular}{|c|c|c|}
\hline مَوْضِعِ الخِبَ & مَوْضِع المُبْتَدَأ & مَوْضِع الابْتِداء \\
\hline كِتّاب & $\varnothing$ & $\varnothing$ \\
\hline كِتاب & هذا & إِنَّ \\
\hline
\end{tabular}

\footnotetext{
71 Sîbeveyhi, el-Kitâb, 2/199.

72 Abdurrahmân el-Hâc Sâlih, Buhûs ve Dirâsât fi'l-Lisâniyyâti'l-'Arabiyye, 2/11-12, 50.

73 Abdurrahmân el-Hâc Sâlih, el-Bune'n-Nahviyyetu'l-'Arabiyye, 64.

${ }^{74}$ Abdurrahmân el-Hâc Sâlih, Buhûs ve Dirâsât fi'l-Lisâniyyâti'l-'Arabiyye, 2/12-13.
} 
Abdurrahmân el-Hâc Sâlih buradan şu sonuçlara ulaşmaktadır: Mevdı', terkip düzeyinde cümlenin yapısının gerektirdiği soyut, itibarî ve takdirî bir konuma $^{75}$ denk düșer. Mevdı dilsel birimden hâlî olabilir. Diğer bir ifadeyle cümlenin bazı parçaları söylenmemiş olabilir; ancak bu parçaların mevd'ıları sabittir ve cümlenin soyut kalıbı (misâl) içerisinde bu mevdılar gösterilirler. ${ }^{76} \mathrm{Bu}$ durum erken dönem nahiv bilginlerinin bir yapı olarak cümle ile konuşma olayındaki cümleyi birbirinden ayırdıklarını ve dilin işlevsel yönüyle biçimsel yönünü ayrı ayrı değerlendirdiklerini göstermektedir. ${ }^{77}$

Abdurrahmân el-Hâc Sâlih'in 'âmil kavramıla birlikte ele aldığı bir kavram 'alâme 'ademiyye (العَلامَة العَدَمِيَّة) kavramıdır. Arap dilinde müfred, müzekker ve mükebber gibi kategoriler asıl; müsennâ/cem, müennes ve musaggar gibi kategoriler ise fer ${ }^{c}$ konumundadır. Asıl değişmeyen ve devamlılık gösteren ögedir. Nitekim asıl, tüm fer'lerinde -zâid ögelerle birlikte- var olmaya devam eder. Bu yüzden fer'î ögeler belirli alametlere ihtiyaç duyarken asılda herhangi bir alamet bulunmaz. Buna göre fer konumundaki birimler, belirli alametlerle asıllarından ayrılmakta ve bu alametler kendilerine ayrılan mevdı içinde gösterilmektedirler. Abdurrahmân el-Hâc Sâlih bu durumu 'alâme 'ademiyye (expression zéro) olarak adlandırır. Örneğin müenneslik tâ'sı, bir alamet olarak kelimeyi asıl konumundaki müzekkerden ayırır ve ismin sonuna eklenerek lafza içindeki yerini (mevdı') alır. Müzekkerlik için ise herhangi bir alamet yoktur. Aynı şekilde tekil-ikil, tekil-çoğul ve mükebbermusaggar karşıtlıklarında asıl konumundaki ögeler, sayı ve büyüklük bildiren alametler taşımaz. Mazi fiil ile muzâri fiil arasında da benzer bir durum söz konusudur. 'Âmil açısından bakıldığında da aynı durumla karşılaşılmaktadır. Nitekim mübtedâ ve haberden oluşan cümlelerde lafzî 'âmil bulunmaz; bu ikisi dışında başka ögeleri de barındıran cümlelerde ise lafzî 'âmiller söz konusudur. ${ }^{78}$

\section{4. 'Âmil}

Abrurrahmân el-Hâc Sâlih'e göre sözdizimsel düzeyi (niveau syntaxique) oluşturan en küçük birim lafza değildir. Zira bu düzeyde başka türden ve daha soyut birimler bulunmaktadır. Buna göre terkip düzeyinde temel birim cümledir. Nahiv bilginleri burada da bir söz oluşturabilecek en küçük yapıdan hareket etmektedirler. Bu yapı birden fazla lafzadan oluşmakta ve asıl/çekirdek olarak kabul

75 Bazı Türkçe-İngilizce dilbilim sözlüklerinde İngilizce position terimin karşılığı olarak kullanılan ve "cümle yapısında, cümlenin kurucularının yer aldığı ve genellikle işlevlerini de belirleyen sıralamadaki yer" şeklinde tanımlanan konum terimi, Abdurrahmân el-Hâc Sâlih'in üzerinde durduğu mevdl' terimiyle bu anlamda benzerlik göstermektedir. Bununla birlikte bazı Arapça-İngilizce dilbilim sözlüklerinde position teriminin mevki (المَوَقِع (المَع terimiyle karşılandığı da görülmektedir. Bk. Kâmile İmer - Ahmet Kocaman - A. Sumru Özsoy, Dilbilim Sözlüğü (İstanbul: Boğaziçi Üniversitesi Yayınevi, 2011), 181; Baalbaki, Dictionary of Linguistic Terms, 387.

76 Abdurrahmân el-Hâc Sâlih, Buhûs ve Dirâsât fi'l-Lisâniyyâti'l-'Arabiyye, 2/13.

77 Abdurrahmân el-Hâc Sâlih, "el-Cumle fî Kitâbi Sîbeveyhi”, 100-101.

78 Abdurrahmân el-Hâc Sâlih, "en-Nahvu'l-'Arabî ve'l-Bineviyye”, 218-219; Abdurrahmân el-Hâc Sâlih, “el-Medrasetu'l-Halîliyyetu'l-Hadîse ve'd-Dirâsâtu'l-Lisâniyyetu'l-Hâliyye fi'l-‘Âlemi'l-'Ârabî”, 36. 
edilmektedir. Örneğin iki lafzadan oluşan "زيدّ قائمع" cümlesi terkip düzeyindeki misâl için bir örnek durumundadır. Zira bu iki lafza, yargı bildiren bir cümle (كلام مفيد) oluşturabilmektedir. ${ }^{79}$ Abrurrahmân el-Hâc Sâlih'e göre;

“Arap nahiv bilginleri anlambirimleri (morfem) Martinet'nin yaptığı gibi cümleleri oluşturan birimler olarak görmezler. Hatta kelime ve lafza da cümleleri oluşturan birimler olarak görülmez. Diğer bir ifadeyle terkip düzeyinde bu düzeye

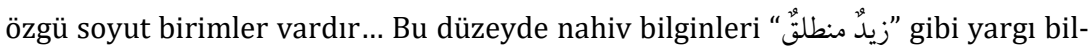
diren bir söz olarak kullanılabilen en küçük birimi hareket noktası olarak alırlar. Sonra bu birime eklenebilecek ziyadelerin neler olduğuna bakılır." 80

Cümle düzeyinde de tıpkı kelime düzeyinde olduğu gibi misâli ortaya çıkarmak için soyutlamaya gidilir. Buna göre cümle için en küçük soyut kalıp (misâl) şu şekildedir: ${ }^{81}$

\begin{tabular}{|c|c|c|}
\hline خَبَرَ & مُبْتَدَأ & $\varnothing$ \\
\hline مَفْعُول & فَاعِل & فِعْل \\
\hline
\end{tabular}

Nahiv bilginleri mübtedâ ve haberden önceki 'âmili ibtidâ (الإبتِّداء) olarak adlandırırlar. Burada ibtidâ ve fiil mevdıllarında inne (إَِّّ), kâne (ََانَ), hasibtu (حَسِبْتُ ve a lemtu 'amran (أَعْلَمْتُ عَمْرًا) gibi başka âmiller de bulunabilmektedir. ${ }^{82}$ Haml, icrâ ve dönüştürüm işlemleri sonucunda söz konusu asıl/çekirdek birim üzerinde inne, kâne, hasibe gibi ziyadeler yapılabilmektedir. Burada öne çıkan husus, cümlenin önüne yapılan eklemelerin cümleyi hem lafız hem de anlam bakımından etkilemesidir. Nitekim kelimelerin sonundaki icrâb alametleri söz konusu eklemelerle değişebilmektedir. Nahiv bilginleri buradan hareketle dönüştürüme ilişkin soyut bir yapıya (مِثال تَّْوِيلي) ulaşmaktadırlar. Abdurrahmân el-Hâc Sâlih, bunu şu şekilde göstermektedir: 83

\begin{tabular}{|c|c|c|}
\hline قَائمْ مُ & زَيْدُ & $\varnothing$ \\
\hline قَائمْ & زَيْدًا & إنَّ \\
\hline قائًَا & زَيْدُ & كان \\
\hline قائِّا & زَيْدًا & حَسِبْتُ \\
\hline قائًً & زَيْدًا & أَعْلَمْتُ عَمْرًا \\
\hline
\end{tabular}

${ }^{79}$ Abdurrahmân el-Hâc Sâlih, "el-Medrasetu'l-Halîliyyetu'l-Hadîse ve'd-Dirâsâtu'l-Lisâniyyetu'l-Hâliyye fi'l-'Âlemi'l-'Ârabî”, 36-37.

80 Abdurrahmân el-Hâc Sâlih, "el-Medrasetu'l-Halîliyyetu'l-Hadîse ve Meşâkilu 'illâci'l-'Arabiyye bi'lHâsûb", 80.

${ }^{81}$ Abdurrahmân el-Hâc Sâlih, Buhûs ve Dirâsât fi'l-Lisâniyyâti'l-'Arabiyye, 2/73-74.

${ }^{82}$ Abdurrahmân el-Hâc Sâlih, Buhûs ve Dirâsât fi'l-Lisâniyyâti'l-'Arabiyye, 2/74.

83 Abdurrahmân el-Hâc Sâlih, "el-Medrasetu'l-Halîliyyetu'l-Hadîse ve'd-Dirâsâtu'l-Lisâniyyetu'l-Hâliyye fi'l-'Âlemi'l-'Ârabî”, 36-37. 


\begin{tabular}{|l|l|l|}
\hline 3 & 2 & 1 \\
\hline
\end{tabular}

Bir numaralı sütundaki unsurlar, cümlenin geri kalanı üzerinde etkide bulunmakta ve bu yüzden 'âmil olarak adlandırılmaktadırlar. 'Âmil, görüldüğü üzere

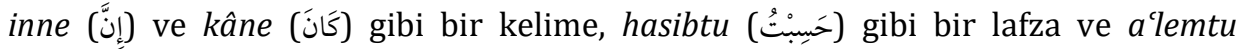
'amran (أَعَعْمَتُ عَمْرًاً ) gibi tam bir terkip de olabilmektedir. 'Âmilden etkilenen unsurlar birinci ma'mûl ve ikinci ma'mûl olarak adlandırılırlar. 'Âmilin mevdı'ı birinci satırdaki örnekte görüldüğü üzere lafzî bir unsurdan hâlî olabilir (خُخُوْ المَوْضِعِ). Nahiv bilginlerinin burada manevî 'âmil olarak ifade ettikleri ibtidâ kavramı, Abdurrahmân el-Hâc Sâlih'e göre kelimenin cümle başında bulunmasını değil, öncesindeki bir unsurla ilişkisinin olmayışını (عَدَم التَّبَعِيَّة) ifade etmektedir. ${ }^{84}$

Abrurrahmân el-Hâc Sâlih'e göre Halîl ve Sîbeveyhi, cümle düzeyinde misâl ve 'âmil hususunda şu noktaları tespit etmişlerdir: Birincisi; Arap dilinde cümleyi oluşturacak en küçük yapı 'âmil ve birinci ma'mûldür ki bu da fiil cümlesinde fiil ve fâil olarak ortaya çıkar. İsim cümlesinde ise ikinci ma'mûle ihtiyaç vardır. İkincisi; birinci ma'mûl 'âmiline takaddüm ${ }^{85}$ edemez. Üçüncüsü; 'âmil inne, kâne veya herhangi bir fiil gibi müfred bir kelime olabileceği gibi hasibtu gibi kendi içinde 'âmil ve ma'mûlden oluşan bir lafza da olabilir. Yine 'âmil, a lemtu Amran gibi kendi içinde 'âmil, birinci ma'mûl ve ikinci ma'mûlden oluşan bir cümle de olabilir. Dördüncüsü; ma'mûlde asıl olan isim olmaktır. Ancak altı durumda fiil de ma'mûl olarak bulunabilmektedir. 86

Özetle 'âmil ve ma‘mûl bir çekirdek olarak cümlenin gramatik yapısını oluşturmaktadır. Cümlenin anlamsal yapısı ise Sîbeveyhi'nin belirttiği üzere müsned ve müsnedün ileyh'ten oluşur. Dolayısıyla bu iki düzey tıpkı gramatik fâil anlamsal fâilde olduğu gibi birbirine karıştırılmamalıdır. ${ }^{87}$

Nahiv bilginleri 'âmil, birinci ma'mûl ve ikinci ma'mûl mevdı'larından oluşan soyut kalıbı (misâl), lafza fi liyye (كَفََْة فِعْلِيَّة barındıran cümleler için de kullanmışlardır. Buna göre "Zeydun kâimun" (زَيْدُ قَائمع (j) cümlesindeki birinci ma'mûl olan Zeyd yerine bir lafza ficliyye de gelebilmektedir: ${ }^{88}$

${ }^{84}$ Abdurrahmân el-Hâc Sâlih, “el-Medrasetu'l-Halîliyyetu'l-Hadîse ve'd-Dirâsâtu'l-Lisâniyyetu'l-Hâliyye fi'l-'Âlemi'l-'Ârabî”, 37; Abdurrahmân el-Hâc Sâlih, "el-Medrasetu'l-Halîliyyetu'l-Hadîse ve Meșâkilu 'İlâci'l-‘Arabiyye bi'l-Hâsûb”, 81.

85 Müberred'in (ö. 286/900), birinci ma‘mûlün 'âmiline takaddüm edebileceğini savunan Ahfeş (ö. 215/830) ve Kûfe ekolüne mensup bazı dilcilere yönelttiği eleștiriler ve konuya ilişkin ayrıntılı bir değerlendirme için bk. el-Müberred, el-Muktedab, 4/128; Kemâlüddîn Abdurrahmân b. Muhammed el-Enbârî, Esrâru'l-'Arabiyye, thk. Muhammed Behcet el-Baytâr (Dımaşk: Matbû'âtu'l-Meceme'i'l'İlmiyyi'l-'Arabî, 1957), 79-83.

${ }^{86}$ Abdurrahmân el-Hâc Sâlih, Buhûs ve Dirâsât fi'l-Lisâniyyâti'l-'Arabiyye, 2/74-75.

87 Abdurrahmân el-Hâc Sâlih, Buhûs ve Dirâsât fi'l-Lisâniyyâti'l-'Arabiyye, 2/75.

88 Abdurrahmân el-Hâc Sâlih, “el-Medrasetu'l-Halîliyyetu'l-Hadîse ve'd-Dirâsâtu'l-Lisâniyyetu'l-Hâliyye fi'l-'Âlemi'l-`Ârabî”, 38. 


\begin{tabular}{|c|c|c|}
\hline قَََعِيْم & زَيْيُدُ & $\varnothing$ \\
\hline 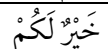 & أَنْنْ تَصُو مُو اِ & $\varnothing$ \\
\hline
\end{tabular}

Nahiv bilginleri 'âmil, birinci ma'mûl ve ikinci ma'mûl mevdı́larından oluşan soyut kalıbı (misâl), fiil cümleleri için de uygulamışlar ${ }^{89}$ ve bu cümlelerde fiilin 'âmil mesabesinde olduğunu tespit etmişlerdir. Nitekim fiil, cümlenin geri kalanını etkileyerek fâil ile mef ûlün i'râb alametlerini belirlemektedir. Burada fâil birinci ma'mûl, mef' ûl ise ikinci ma'mûldür: ${ }^{90}$

\begin{tabular}{|c|c|c|}
\hline قَائمِمُ & زَيْدُ & $\varnothing$ \\
\hline خَيْرِ لَكُمْ & أَنْ تَصُوُْوُوا & $\varnothing$ \\
\hline زَيْدًا & ــ & رَأَيْهـ \\
\hline ــكَكَ" & ــ & رَأَيْـــ \\
\hline
\end{tabular}

Görüldüğü üzere birinci ve ikinci macmûl mevdı'larında bir kelime (زَيْدَادَ), bir

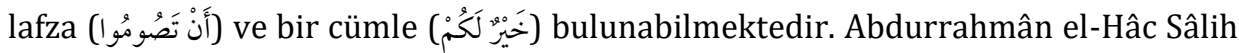
buradan hareketle şu yargıya ulaşmaktadır: "Terkibi (cümleyi) oluşturan unsurlar

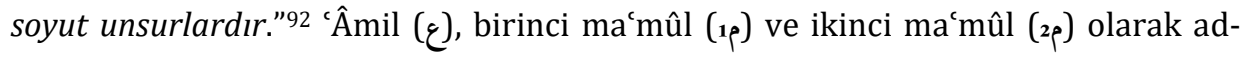
landırılan bu temel unsurların devamında cümleye başka unsurlar da eklenebilmektedir. Mef ûl bih dışındaki diğer mef ûller ve hâl gibi tahsis edici ögeler (خ) bu gruba dâhildir. Nahiv bilginlerinin eklenip çıkarılabilen ögeler olarak adlandırdıkları bu ögeler, çekirdek yapıya ait olmayan (فَضَضَْائد ( فَلَ) tahsis edici birimlerdir

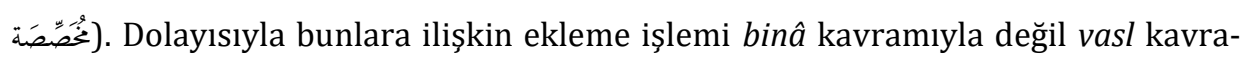
mılla ifade edilir. ${ }^{93}$

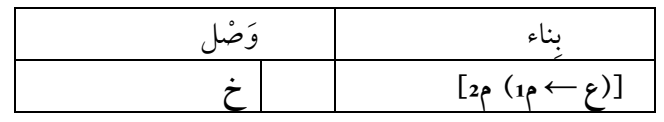

89 'Amil ve ma'mûl, görüldüğü üzere bir asıl oluşturmakta ve bu asıldan çok sayıda fer' ortaya çıkmaktadır. Abdurrahmân el-Hâc Sâlih ve Abduh er-Râcihî’ye göre üretici-dönüşümsel dilbilgisi kuramında nahiv ilmindeki 'âmil kavramına benzer şekilde önemli yaklaşım biçimleri bulunmaktadır. Bk. Abdurrahmân el-Hâc Sâlih, "en-Nahvu'l-'Arabî ve'l-Bineviyye", 199; Abduh erRâcihî, en-Nahvu'l-'Arabî ve'd-Dersu'l-Hadîs (Beyrut: Dâru'n-Nahdati'l-'Arabiyye, 1979), 147-149.

${ }^{90}$ Abdurrahmân el-Hâc Sâlih, "el-Medrasetu'l-Halîliyyetu'l-Hadîse ve'd-Dirâsâtu'l-Lisâniyyetu'l-Hâliyye fi'l-'Âlemi'l-'Ârabî”, 38.

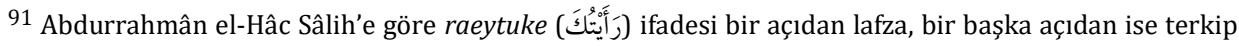
(cümle) olarak kabul edilmektedir.

92 Abdurrahmân el-Hâc Sâlih, "el-Medrasetu'l-Halîliyyetu'l-Hadîse ve'd-Dirâsâtu'l-Lisâniyyetu'l-Hâliyye fi'l-'Âlemi'l-'Ârabî", 38.

93 Abdurrahmân el-Hâc Sâlih, "el-Medrasetu'l-Halîliyyetu'l-Hadîse ve'd-Dirâsâtu'l-Lisâniyyetu'l-Hâliyye fi'l-'Âlemi'l-'Ârabî”, 38. 
Mef ${ }^{\mathrm{u}} \mathrm{u}$ bih dişındaki tüm mef ${ }^{\mathrm{f}}$ ûller, temyiz, hâl ve müstesnâ tahsis edici birimler grubuna girer. Mef'ûl bih cümlenin tamamlanması (ifâde) açısından fazla olsa da gramatik/lafzî yapı açısından temel unsurdur. Nitekim mef ûl bih isim cümlesindeki haber mesabesindedir. ${ }^{94}$

\begin{tabular}{|c|c|c|}
\hline فَ| فَاعِلَ & $\varnothing$ \\
\hline
\end{tabular}

Abdurrahmân el-Hâc Sâlih'in 'âmil kavramıyla birlikte ele aldığı bir kavram tasdîr (التَّصْدِير) kavramıdır. Tasdîr; 'âmil, ma'mûl ve muhassıs mevdı`larını aşan bir mevdı'ı göstermektedir. Buna göre mutlak surette yapının başında bulunan ( الصَّدَارَة (المُطْلَةَ ve nahiv bilginlerinin hurûfu'l-ibtidâ olarak adlandırdıkları bazı edatlar, yapının tamamı üzerinde etkili olmaktadırlar. Ancak bu edatların írâb alametlerini değiștirmeleri gerekmez. İstifhâm, tevkîd ve şart edatları bu gruba dâhil olan edatlardandır. ${ }^{95}$

\section{Sonuç}

Yeni Halilcilik Kuramı, dördüncü yüzyıl sonrası nahiv kitaplarının, bazı münferit çalışmalar hariç tutulduğunda, Halîl ve Sîbeveyhi'nin ortaya koydukları nahiv kuramını yansıtmadıkları temel düşüncesine dayanmaktadır. Abdurrahmân el-Hâc Sâlih'e göre Halîl ve Sîbeveyhi'nin çalışmaları gerek içerik gerekse de yöntem açısından gelişmiş ve yüksek kuramlara sahiptir. Dolayısıyla nahiv ilmine ait mevcut literatürün homojen bir yapı arz etmediği söylenmelidir. Halîl b. Ahmed'in başta elKitâb olmak üzere nahiv kitaplarında aktarılan görüşlerinin yeni bir okuması olarak nitelendirilmesi mümkün olan Yeni Halilcilik Kuramı'na göre Halîl b. Ahmed'in ve takipçilerinin geliştirdiği dil kuramı gerek kavramlar gerekse metodoloji bakımından geç dönem nahiv bilginleri tarafından tam olarak değerlendirilmemiştir.

Abdurrahmân el-Hâc Sâlih'e göre Halîl b. Ahmed'in ve Sîbeveyhi'nin dilsel yapılara ilişkin tanımları icrâî bir karaktere sahiptir. Yani bu kuram, gramatik yapıları onların kuruluş keyfiyetlerini belirlemek suretiyle tanımlamakta ve aynı zamanda üretmektedir. Bu da önce asıl birimin belirlenmesi ve daha sonra bu asıldan fer'lerin türetilmesiyle gerçekleşmektedir. Örneğin isim için önce konuşma olayında kullanılabilecek en küçük birim araştırılmakta ve bu birimin aynı zamanda yargı bildiren bir söz olması istenmektedir. Dolayısıyla "Bu nedir?” şeklindeki bir soruya cevap olarak verilen "Kitâb." ifadesi söz konusu asıl birimi oluşturmaktadır. Daha sonra asıl birim üzerinde gerçekleștirilebilecek ziyade işlemlerine bakılarak el-kitâb, bi'l-kitâb, bi'l-kitâbi'l-mufíd gibi fer'ler üretilmektedir. Abdurrahmân el Hâc Sâlih'e göre modern dilbilimdeki dönüștürüm (tahvil) işlemine denk düșen bu

\footnotetext{
${ }^{94}$ Abdurrahmân el-Hâc Sâlih, Buhûs ve Dirâsât fi'l-Lisâniyyâti'l-'Arabiyye, 2/75.

${ }^{95}$ Abdurrahmân el-Hâc Sâlih, "el-Medrasetu'l-Halîliyyetu'l-Hadîse ve'd-Dirâsâtu'l-Lisâniyyetu'l-Hâliyye fi'l-'Âlemi'l-'Ârabî", 39.
} 
üretim (tevlîd), aynı zamanda ilgili birimlerin tanımlanması (tahdîd) anlamına gelmektedir. Bu işlemler neticesinde Yeni Halilcilik Kuramının temel kavramlarından olan mevdl $^{\text {‘ }}$ ve misâl kavramlarına ulaşılmaktadır. Buna göre mevd'c, kitâb ismi etrafındaki harf-i cer, harf-i tarif, i'râb alameti, tenvin veya muzâfun ileyh ve sıfat gibi dilsel birimlerin bütün içindeki -kendine özgü vazîi işlevini yerine getirdiğikonumuna; misâl ise bu konumların toplamı mesabesindeki soyut kalıba ișaret etmektedir. Dolayısıyla kitâb ismine ilişkin altı mevdı' bulunmakta ve bu mevdıların toplamı misâli oluşturmaktadır. Burada Yeni Halilcilik Kuramının temel kavramlarından bir diğeri olan lafza kavramı ön plana çıkmaktadır. Nitekim kitâb kelimesi ile el-kitâb, bi'l-kitâbi, kitâbun mufîd ve kitâbu Zeyd karşıtlıklarında görüldügü üzere lafza kelimeden büyük ve cümleden küçük birimlere işaret etmektedir. Abdurrahmân el-Hâc Sâlih modern dilbilimde bulunmadığını belirttiği lafza kavramını karşılamak için lexie terimini önermiștir. Burada Abdurrahmân el-Hâc Sâlih, dilsel birimlere ilişkin üçlü bir tasnif yaparak anlambirim, kelime ve lafza kavramları arasındaki ilişkiye açıklık getirmiştir. Buna göre anlambirim kavramı, kelime kavramıla her zaman örtüşmemektedir. Nitekim mufîd kelimesindeki mîm anlambirimi, bir kelime değildir. Lafzanın ise birden fazla anlambirimin bir araya gelmesinden oluştuğu görülmektedir.

Abdurrahmân el-Hâc Sâlih'in misâl ve lafza kavramlarıyla ilgili olarak vurguladığı bir husus, misâlin "bi kitâbi Zeydin el-müfîd" örneğinde görüldügü üzere lafza düzeyinde ortaya çlktığı gibi kelime ve cümle düzeylerinde de görülmesidir. Buna göre Arap dili tüm düzeylerde misâllere sahiptir. Nahiv bilginleri kelime düzeyinde fâ-'ayn-lâm mevdı́larını misâl için değişken simgeler olarak kabul etmekte ve buradan hareketle çok sayıda fer'ler türetmektedirler. Örneğin mef ${ }^{\prime} a l$ ve mef $i l$ ism-i mekân grubuna ait kelimeler için misâl teşkil etmektedir. Cümle düzeyinde ise Halîl ve Sîbeveyhi, misâl için yine en küçük soyut birimi belirlemişlerdir. Bu da Yeni Halilcilik Kuramı'nın temel kavramlarından bir diğeri olan 'âmil kavramını ön plana çıkarmaktadır. Nitekim cümle düzeyinde misâl; 'âmil, birinci ma'mûl ve ikinci ma‘mûl mevdı́larından oluşmaktadır. Bu sıralama, isim cümlesinde ibtidâ, mübtedâ, haber şeklinde; fiil cümlesinde ise fiil, fâil, mef' ûl şeklindedir. Abdurrahmân el-Hâc Sâlih bu tanımlamayı bir soyutlama becerisi olarak yorumlamış ve cümlenin somut kelimelerden değil, sözü edilen soyut unsurlardan oluştuğunu vurgulamıştır. 'Âmil, birinci ma'mûl ve ikinci ma'mûl şeklindeki soyut unsurlardan sonra cümleye eklenen diğer unsurlar ise cümlenin ana yapısına dâhil olmayan tahsis edici ögeler (muhassısât) olarak adlandırılmıştır.

Yeni Halilcilik Kuramının temel kavramlarından bir diğeri istikâmet kavramıdır. Bu kavram her şeyden önce lafza ilişkin hususlarla anlama ilişkin hususlar arasındaki kesin ayrıma işaret etmektedir. Abdurrahmân el-Hâc Sâlih, Sîbeveyhi'nin cümleye ilişkin olarak önce müstakim-hasen ile müstakim-kabih kavramları arasında sonra da bu ikisiyle muhal kavramı arasında kurduğu karşıtlığı öncelikle kıyasa uygun olan ve olmayan lafızlar arasında sonra ise anlamlılık ile anlamsızlık arasında yapılmış bir ayrım olarak yorumlamıştır. Dolayısıyla ifadenin dilin cümle yapısına hâkim olan kurallara uygun olmasıyla anlam sahibi olması arasında fark gözetilmektedir. Abdurrahmân el-Hâc Sâlih erken dönem nahiv bilginlerinin lafız ve anlam arasındaki bu dengeyi gözettiklerini ve dilsel birimleri 
tanımlarken bunlardan birini terk etmediklerini vurgulamakta; kelimenin tanımı konusunda Sîbeveyhi ile sonraki nahivcilerin farklı yaklaşımlara sahip olduklarını belirtmektedir. Abdurrahmân el-Hâc Sâlih'e göre Halîl ve Sîbeveyhi, lafız-mana ayrımı ve istikâmet kavramı bağlamında, nahiv çalışmalarında semantik ve sentaktik düzeyleri esas alan ilk dilciler olarak ortaya çıkmaktadırlar. Bunun anlamı söz konusu iki ismin, cümleye ilișkin anlam ve yargı bildirme düzeyleri ile gramatik yapı arasında ayrım yapmaları ve dilin her iki yönüne ait temel ilkeleri tanımlamayı hedeflemeleridir. Söz konusu ayrımın bir bașka veçhesini Halîl b. Ahmed'in müsta'mel ve mühmel lafızlara ilişkin ifadelerinde görmek mümkündür. Mühmel kıyasın gerektirdiği ancak kullanımda olmayan yapıları ifade etmekte ve Abdurrahmân el-Hâc Sâlih'e göre yüksek bir soyutlama becerisinin ürünü olarak ortaya çıkmaktadır. Abdurrahmân el-Hâc Sâlih'in bu değerlendirmeleri, onun dördüncü yüzyıl nahiv çalışmalarına yönelttiği eleştiriler de dikkate alındığında, nahiv ilminin semantik değerlendirmelerden uzak ve standartları belirlenmiş bir kurallar dizisi olarak görülmesinin yanlışlığına ve dilsel olguları kendi gerçeklikleri içinde bilimsel bir bakış açısıyla tanımlamanın önemine yaptığı bir vurgu olarak ortaya çıkmaktadır.

Funding / Finansman: This research received no external funding. / Bu araştırma herhangi bir diş fon almamıştır.

Conflicts of Interest / Çıkar Çatışması: The author declare no conflict of interest. / Yazar, herhangi bir çıkar çatışması olmadığını beyan eder.

\section{Kaynakça}

Abduh er-Râcihî. en-Nahvu'l-'Arabî ve'd-Dersu'l-Hadîs. Beyrut: Dâru'n-Nahdati'l-'Arabiyye, 1979.

Abdurrahmân el-Hâc Sâlih. Buhûs ve Dirâsât fi'l-Lisâniyyâti'l-'Arabiyye. Cezayir: elMuessesetu'l-Vataniyye li'l-Funûni'l-Matba'iyye, 2012.

Abdurrahmân el-Hâc Sâlih. el-Bune'n-Nahviyyetu'l- 'Arabiyye. Cezayir: Menşûrâtu'l-Mecme'i'lCezâîrî li'l-Lugati'l-'Arabiyye, 2016.

Abdurrahmân el-Hâc Sâlih. "el-Cumle fî Kitâbi Sîbeveyhi". Mecelletu Mecme'i'l-Lugati'l'Arabiyye 78 (Mayıs 1996), 98-113.

Abdurrahmân el-Hâc Sâlih. el-Hitâb ve't-Tehâtub. Cezayir: el-Muessesetu'l-Vataniyye li'lFunûni'l-Matba'iyye, 2012.

Abdurrahmân el-Hâc Sâlih. Mantıku'l-'Arab fí 'Ulûmi'l-Lisân. Cezayir: el-Muessesetu'lVataniyye li'l-Funûni'l-Matba'iyye, 2012.

Abdurrahmân el-Hâc Sâlih. “el-Medrasetu'l-Halîliyyetu'l-Hadîse ve'd-Dirâsâtu'lLisâniyyetu'l-Hâliyye fi'l- 'Âlemi'l- 'Ârabî”. Kurrâsetu Merkezi'l-Bahsi'l- 'İlmî ve't-Tekanî li Tatvîri'l-Lugati'l-'Arabiyye 4 (2007), 15-46.

Abdurrahmân el-Hâc Sâlih. “el-Medrasetu'l-Halîliyyetu'l-Hadîse ve Meșâkilu 'illâci'l'Arabiyye bi'l-Hâsûb”. Kurrâsetu Merkezi'l-Bahsi'l-'İlmî ve't-Tekanî li Tatvîri'l-Lugati'l'Arabiyye 4 (2007), 49-95.

Abdurrahmân el-Hâc Sâlih. "Mukaddime". Kurrâsetu Merkezi'l-Bahsi'l-'ilmî ve't-Tekanî li Tatvîri'l-Lugati'l-'Arabiyye 4 (2007), 5-11.

Abdurrahmân el-Hâc Sâlih. "en-Nahvu'l-'Arabî ve'l-Bineviyye”. Mecelletu Mecme ii'lLugati'l'Arabiyye 85 (Mayıs 1990), 197-219.

Baalbaki, Ramzi Munir. Dictionary of Linguistic Terms. Beirut: Dar El-Ilm Lilmalayin, 1990.

Câbirî, Muhammed Âbid. Binyetü'l-'Akli'l-'Arabî. Beyrut: Merkezu Dirâsâti'l-Vahdeti'l- 
'Arabiyye, 2009.

Enbârî, Kemâlüddîn Abdurrahmân b. Muhammed. Esrâru'l-'Arabiyye. thk. Muhammed Behcet el-Baytâr. Dımaşk: Matbû́âtu'l-Meceme 'i'l-'Illmiyyi'l-'Arabî, 1957.

Esterâbâdî, Radıyyuddîn. Şerhu Șâfiyeti İbni'l-Hâcib. thk. Muhammed Nûr el-Hasen vd. 3 Cilt. Kahire: Dâru'l-Kutubi'l-'ilmiyye, 1982.

Gündüzöz, Soner. Arap Düşüncesinin Büyübozumu. Samsun: Etüt Yayınları, 2011.

Hâdî Nehr. 'İlmu'd-Delâle et-Tatbîkî fi't-Turâsi'l-'Arabî. İrbid: Dâru'l-Emel, 2007.

Halîl Ahmed 'Amâyira. Fî Nahvi'l-Luga ve Terâkîbihâ Menhec ve Tatbîk. Cidde: 'Alemu'lMa'rife, 1984.

Halîl b. Ahmed. Kitâbu'l-'Ayn. thk. Mehdî el-Mahzûmî-İbrahim es-Sâmerrâî. 8 Cilt. Beyrut: Mektebetu'l-Hilâl.

İbn Cinnî, Ebu'l-Feth Osmân. el-Hasâis. thk. Muhamed Ali en-Neccâr. 3 Cilt. Kahire: elHey'etu'l-'Âmme li Kusûri's-Sekâfe, 2006.

İbn Mâlik, Cemâlüddîn Muhammed b. Abdillah. Şerhu Teshîli'l-Fevâid ve Tekmîli'l-Makâsıd. thk. Abdülkâdir 'Atâ - Târık Fethî es-Seyyid. 3 Cilt. Beyrut: Dâru'l-Kutubi'l-'İlmiyye, 2001.

İbnü'l-Haşşâb, Ebû Muhammed Abdullah b. Ahmed. el-Mürtecel. thk. Ali Haydar. Dımaşk: 1972.

İbrahim Medkûr. “Mantıku Aristo ve'n-Nahvu'l-'Arabî”. Mecelletu Mecme 'i'l-Lugati'l'Arabiyye 7 (1953), 338-346.

İmer, Kâmile - Kocaman, Ahmed - Özsoy, A. Sumru. Dilbilim Sözlüğü. İstanbul: Boğaziçi Üniversitesi Yayınevi, 2011.

Lecnetu'l-Vataniyye li'z-Zehîrati'l-Lugaviyye. "es-Sîratu'z-Zâtiyye li'l-Ustâz ed-Duktûr Abdurrahmân el-Hâc Sâlih". Erișim 22 Temmuz 2021. https://www.cndhakhiraalarabiyya.dz/

Muhammed Hamâse Abdüllatîf. en-Nahv ve'd-Delâle. Kahire: Dâru'ş-Şurûk, 2000.

Murâdî, Bedruddîn el-Hasen b. Kâsım. el-Cene'd-Dânî fî Hurûfi'l-Me'ânî. thk. Fahruddîn Kabâve - Nedim Fâdıl. Beyrut: Dâru'l-Kutubi'l-'̇lmiyye, 1992.

Müberred, Ebu'l-Abbâs Muhammed b. Yezîd. el-Muktedab. thk. Muhammed Abdulhâlik 'Uzayme. 4 Cilt. Kahire: 1994.

Rummânî, Ebu'l-Hasen Ali b. İsa. Şerhu Kitâbi Sîbeveyhi. thk. Muhammed İbrahim Yûsuf Şeybe. 2 Cilt. Mekke: Ümmü'l-Kurâ Üniversitesi, 1415.

Saîd Hasen Buhayrî. 'Anâsıru'n-Nazariyyeti'n-Nahviyye fî Kitâbi Sîbeveyhi. Kahire: Mektebetu'l-Anglo el-Misriyye, 1989.

Sîbeveyhi. Ebû Bişr Amr b. Osmân. el-Kitâb. thk. Abdusselâm Muhammed Harun. 5 Cilt. Kahire: Mektebetu'l-Hancî, 1988.

Sîrâfî, Ebû Saîd. Șerhu Kitâbi Sîbeveyhi. thk. Ramazan Abduttevvâb vd. 18 Cilt. Kahire: Dâru'lKutub ve'l-Vesâiku'l-Kavmiyye, 2008.

Şevkî Dayf. "Takdim”. Buhûs ve Dirâsât fi'l-Lisâniyyâti'l-'Arabiyye. mlf. Abdurrahmân el-Hâc Sâlih. 1/7-8. Cezayir: el-Muessesetu'l-Vataniyye li'l-Funûni'l-Matba'iyye, 2012.

Vardar, Berke. Açılklamalı Dilbilim Terimleri Sözlüğü. İstanbul: Multilingual Yabancı Dil Yayınları, 2002.

Verde Suhrî. el-Cuhûdu'l-Lisâniyye 'inde'd-Duktûr Abdurrahmân el-Hâc Sâlih min hilâli Buhûs ve Dirâsât fî 'Ulûmi'l-Lisân. Batna: Câmiatu Batna, Kulliyyetu'l-Luga ve'l-Edebi'l'Arabî ve'l-Funûn, Yüksek Lisans Tezi, 2016. 